\begin{tabular}{|c|c|c|c|c|c|}
\hline \multicolumn{6}{|c|}{ DISTRIBUTION SHEET } \\
\hline To & \multirow{2}{*}{\multicolumn{3}{|c|}{$\begin{array}{l}\text { From } \\
\text { M. J. Kupfer }\end{array}$}} & \multicolumn{2}{|l|}{ Page 1 of 2} \\
\hline Distribution & & & & \multicolumn{2}{|c|}{ Date $12 / 19 / 94$} \\
\hline \multicolumn{4}{|l|}{ Project Title/Work Order } & \multicolumn{2}{|c|}{ EDT No. 609347} \\
\hline \multicolumn{4}{|c|}{$\begin{array}{l}\text { WHC-SD-WM-TA-154, Rev 0, Strategy for Sampling Hanford Site Tank } \\
\text { Wastes for Development of Disposal Technology }\end{array}$} & \multicolumn{2}{|l|}{ ECN No. } \\
\hline Name & MSIN & $\begin{array}{c}\text { Text } \\
\text { With All } \\
\text { Attach. }\end{array}$ & Text Only & \begin{tabular}{c|c} 
Attach./ \\
& $\begin{array}{c}\text { Appendix } \\
\text { Only }\end{array}$ \\
\end{tabular} & $\begin{array}{l}\text { EDT/ECN } \\
\text { Only }\end{array}$ \\
\hline $\begin{array}{l}\text { DOE/RL } \\
\text { S. T. Burnum } \\
\text { J. M. Clark } \\
\text { L. Erickson } \\
\text { P. T. Furlong } \\
\text { R. E. Gerton } \\
\text { R. A. Gilbert } \\
\text { P. E. Lamont } \\
\text { J. C. Peschong }\end{array}$ & $\begin{array}{l}57-53 \\
57-54 \\
57-53 \\
57-52 \\
57-54 \\
57-53 \\
57-53 \\
S 7-53\end{array}$ & $\begin{array}{l}x \\
X \\
x \\
X \\
X \\
x \\
X \\
x\end{array}$ & & & \\
\hline $\begin{array}{l}\text { PNL } \\
\text { N. G. Colton } \\
\text { P. Eller } \\
\text { L. K. Holton, Jr. } \\
\text { G. J. Lumetta } \\
\text { G. B. Mellinger } \\
\text { B. M. Rapko } \\
\text { E. A. Schmiemen } \\
\text { J. T. Slankas } \\
\text { D. M. Strachan } \\
\text { J. L. Swanson }\end{array}$ & $\begin{array}{l}K 3-75 \\
B 1-40 \\
K 9-73 \\
P 7-25 \\
K 9-81 \\
P 7-25 \\
K 9-81 \\
K 9-81 \\
K 9-78 \\
P 7-25\end{array}$ & $\begin{array}{l}X \\
X \\
X \\
X \\
X \\
X \\
X \\
X \\
X \\
X\end{array}$ & & & \\
\hline $\begin{array}{l}\text { WHC } \\
\text { Central Files }(2) \\
\text { OSTI (2) } \\
\text { W. T. Alumkal } \\
\text { J. N. Appel } \\
\text { H. Babad } \\
\text { S. K. Baker } \\
\text { S. A. Barker } \\
\text { W. B. Barton } \\
\text { G. D. Bazinet } \\
\text { J. H. Beeman } \\
\text { M. L. Bell } \\
\text { R. J. Blanchard } \\
\text { A. L. Boldt } \\
\text { K. D. Boomer } \\
\text { G. L. Borsheim } \\
\text { D. R. Bratzel } \\
\text { T. M. Brown } \\
\text { J. M. Colby } \\
\text { J. M. Conner } \\
\text { C. Defigh-Price } \\
\text { D. A. Dodd } \\
\text { G. L. Dunford }\end{array}$ & 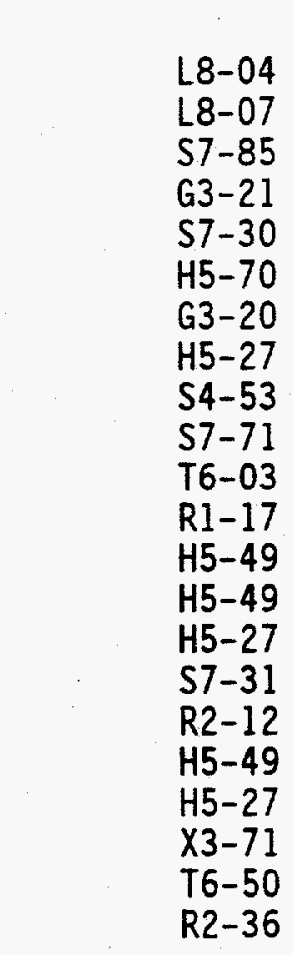 & 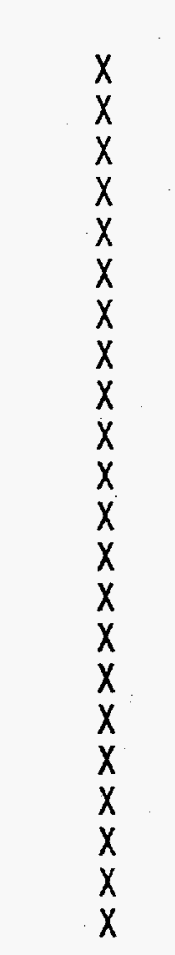 & & & \\
\hline
\end{tabular}




\section{DISCLAIMER}

Portions of this document may be illegible in electronic image products. Images are produced from the best available original document. 
DISTRIBUTION SHEET

\begin{tabular}{|c|c|c|c|c|c|}
\hline \multirow{2}{*}{$\begin{array}{l}\text { To } \\
\text { Distribution }\end{array}$} & \multirow{2}{*}{\multicolumn{3}{|c|}{$\begin{array}{l}\text { From } \\
\text { M. J. Kupfer }\end{array}$}} & \multicolumn{2}{|l|}{ Page 2 of 2} \\
\hline & & & & \multicolumn{2}{|c|}{ Date $12 / 19 / 94$} \\
\hline \multicolumn{4}{|l|}{ Project Title/Work Order } & \multicolumn{2}{|c|}{ EDT No. 609347} \\
\hline \multicolumn{4}{|c|}{$\begin{array}{l}\text { WHC-SD-WM-TA-154, Rev 0, Strategy for Sampling Hanford Site Tank } \\
\text { Wastes for Development of Disposal Technology }\end{array}$} & \multicolumn{2}{|l|}{ ECN No. } \\
\hline Name & MSIN & $\begin{array}{c}\text { Text } \\
\text { With All } \\
\text { Attach. }\end{array}$ & Text Only & $\begin{array}{l}\text { Attach./ } \\
\text { Appendix } \\
\text { Only }\end{array}$ & $\begin{array}{l}\text { EDT/ECN } \\
\text { Only }\end{array}$ \\
\hline
\end{tabular}

S. D. Eberlein

L. F. Ermold

G. D. Forehand

J. S. Garfield

K. A. Gasper

M. L. Grygiel

C. S. Haller

B. A. Higley

J. G. Hill

J. 0 . Honeyman

L. Jensen

$R$. D. Jensen

M. E. Johnson

L. J. Johnson

T. J. Kelley

N. W. Kirch

R. A. Kirkbridge

M. J. Kupfer (20)

S. L. Lambert

D. J. McCain

G. A. Meyer

W. C. Miller

R. J. Murkowski

R. M. Orme

M. A. Payne

W. A. Peiffer

R. S. Popielarczyk

R. W. Powell

I. E. Reep

D. A. Reynolds

R. C. Roal

P. S. Schaus

R. D. Schreiber

W. W. Schulz

L. W. Shelton

E. J. Shen

B. C. Simpson

J. P. Sloughter

G. A. Stanton, Jr.

J. A. Swenson

A. M. Umek

D. J. Washenfelder

E. T. Weber

D. D. Wodrich

R. D. Wojtasek
S7-31

S7-04

S7-31

H5-49

G3-21

B1-59

R2-12

H5-27

K7-97

S7-81

T6-07

B1-58

B] -58

H5- 49

S7 -30

R2-11

H5-27

H5- 49

H5-27

S7-30

$54-54$

S4-55

R4-01

H5-27

S7-14

H5-49

RI -30

H4-14

G3-21

R2-11

H5-27

H4- 14

R2-12

H5- 49

H5- 49

54-58

R2-12

T6-07

57-21

G6-45

S7-81

H5-27

H5-27

57-84

S7-84 $x$
$x$
$x$
$x$
$x$
$x$
$x$
$x$
$x$
$x$
$x$
$x$
$x$
$x$
$x$
$x$
$x$
$x$
$x$
$x$
$x$
$x$
$x$
$x$
$x$
$x$
$x$
$x$
$x$
$x$
$x$
$x$
$x$
$x$
$x$
$x$
$x$
$x$
$x$
$x$
$x$
$x$
$x$
$x$
$x$ 


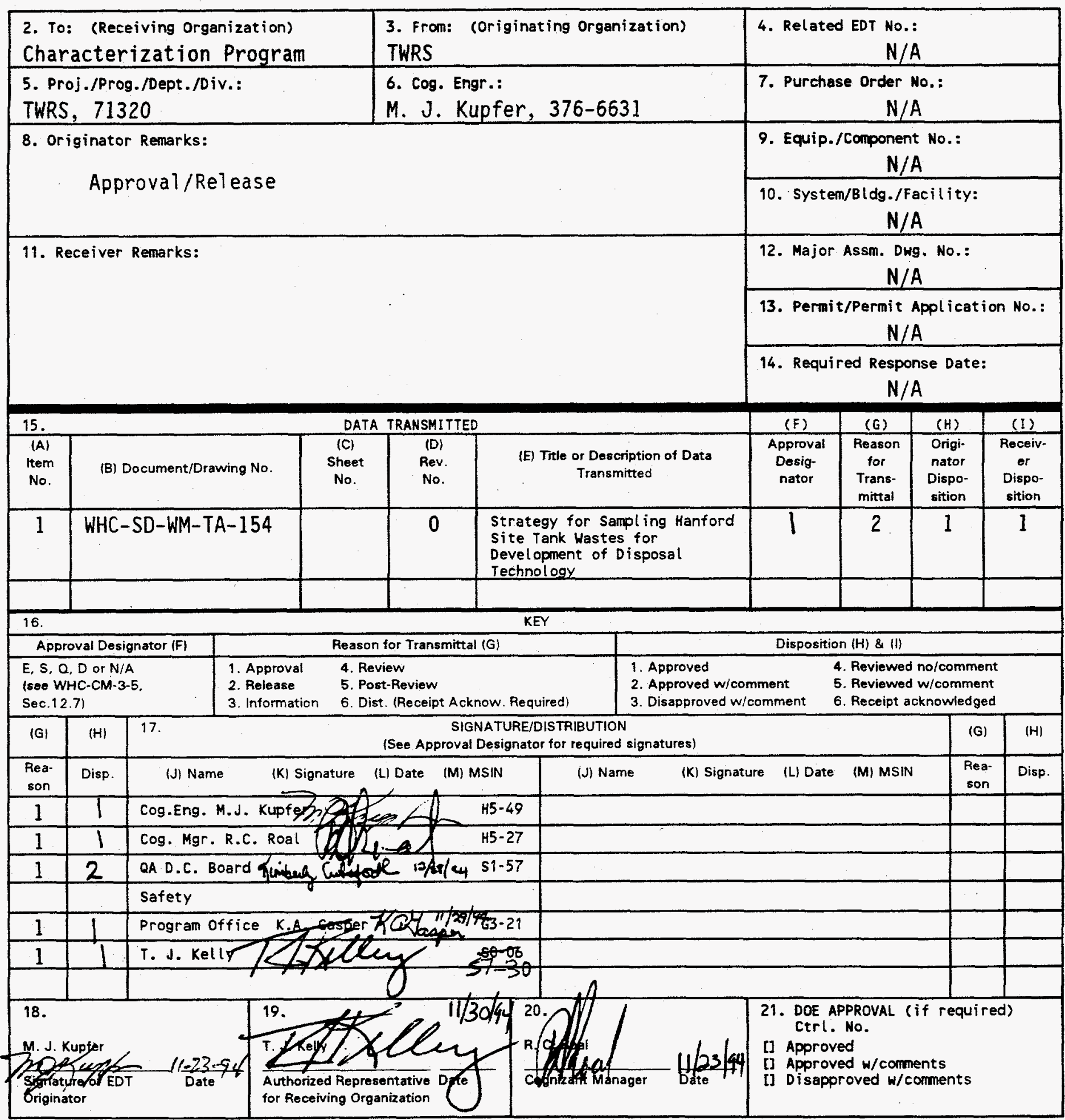




\section{RELEASE AUTHORIZATION}

Document Number: WHC-SD-WM-TA-154, Revision 0

Document Tite: $\quad$ Strategy for Sampling Hanford Site Tank Wastes for Development of Disposal Technology

Releace Date: $\quad$ December 29, 1994

This document was reviewed following the procedures described in WHC-CM-3-4 and is:

APPROVED FOR PUBLIC RELEASE

WHC Information Release Administration Specialist:

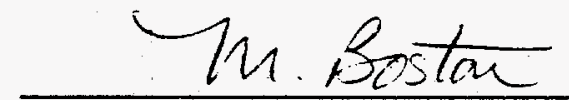

\section{M.N. Boston}

TRADEMARK DISCLAIMER. Reference herein to any specific commercial product, process, or service by trade name, trademark, manufacturer, or otherwise, does not necessarily constitute or imply its endorsement, recomendation, or favoring by the United states Government or any agency thereof or its contractors or subcontractors.

This report has been reproduced from the best ovailable capy. Available in paper copy and microfiche. Printed in the United States of America. Available to the U.S. Department of Energy and its contractors from:

U.S. Department of Energy

Office of Scientific and Technical information (OSTI)

P.0. Box 62

Dak Ridge, TI 37831

Telephone: (615) 576-8401

Available to the public from:

U.S. Depertiment of Commerce

Notional Technical Information service (NTIS)

5285 Port Royal Roed

Sprinofield, VA 22161

Telephone: (703) $487-4650$ 
2. Title

Strategy for Sampling Hanford Site Tank Wastes for Development of Disposal Technology

5. Key Words

Tank Wastes, Tank Samples, Disposal

Strategy, Double-Shel1 Tanks, Single-She 11 Tanks

3. Number

WHC-SD-WM-TA-154

4. Rev No.

0
6. Author

Name: M. J. Kupfer

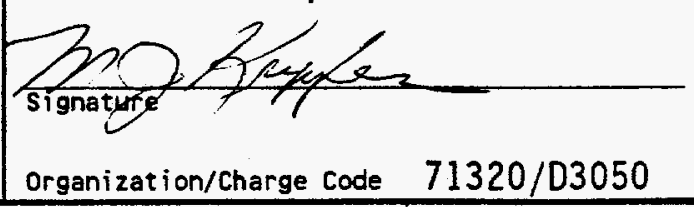

\section{Abstract}

This document explains the tank waste sampling strategy needed to obtain the information required to identify and develop pretreatment and waste immobilization processes. The key tenet of the strategy is that process testing with real waste material from the Hanford Site underground tanks is necessary to design processes and measure their effectiveness. This document provides the criteria for selection of a limited number of tanks to be sampled. A phased, iterative approach is used for the single-shell tank (SST) waste sampling. In the first sampling phase, samples are taken from 25 tanks which provide a good representation of the waste types of interest. Results from process testing of these samples will be considered in final selection of a limited number of additional SSTs to sample (currently expected to be an additional 14 tanks).

\section{DISCLAIMER}

This report was prepared as an account of work sponsored by an agency of the United States Government. Neither the United States Government nor any agency thereof, nor any of their employees, makes any warranty, express or implied, or assumes any legal liability or responsibility for the accuracy, completeness, or usefulness of any information, apparatus, product, or process disclosed, or represents that its use would not infringe privately owned rights. Reference herein to any specific commercial product, process, or service by trade name, trademark, manufacturer, or otherwise does not necessarily constitute or imply its endorsement, recommendation, or favoring by the United States Government or any agency thereof. The views and opinions of authors expressed herein do not necessarily state or reflect those of the United States Government or any agency thereof.
8. RELEASE STAMP

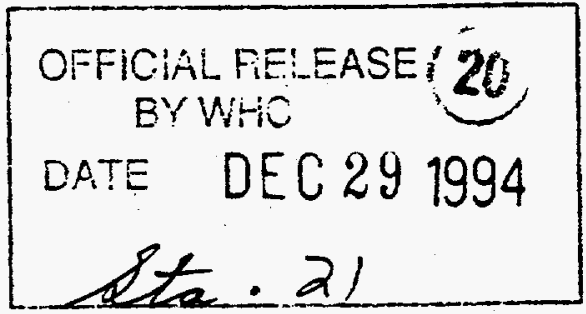


WHC-SD-WM-TA-154

Revision 0

\section{STRATEGY FOR SAMPLING HANFORD SITE TANK WASTES FOR DEVELOPMENT OF DISPOSAL TECHNOLOGY}

November 1994
M. J. Kupfer
W. W. Schulz
G. L. Borsheim
S. J. Eberlein
B. C. Simpson
J. T. Slankas

Westinghouse Hanford Company

Richl and, Washington 
WHC-SD-WM-TA-154

Revision 0

This page intentionally left blank. 


\title{
STRATEGY FOR SAMPLING HANFORD SITE TANK WASTES FOR DEVELOPMENT OF DISPOSAL TECHNOLOGY
}

\begin{abstract}
This document explains the strategy to obtain the information required to identify and develop pretreatment and waste immobilization processes. The key tenet of the strategy is that process testing with real waste material from the Hanford Site underground tanks is necessary to design processes and measure their effectiveness. It is not cost effective to obtain and test samples from all tanks; however, tanks can be grouped based on similarities in the waste streams that entered the tanks. Samples of waste materials from key tanks will provide material representative of major waste types and representative of bounding waste types that will prove limiting for the processes. This document provides the criteria for selection of the limited number of tanks to be sampled.

A second element of the strategy uses the results of selective sampling and process testing to confirm the historical information used in tank grouping. Existing information indicates that the tank grouping strategy is sound. Selected process development studies will provide confidence in the grouping for the primary analytes of concern to the pretreatment and disposal programs. Details of requested analyses will be provided in the Pretreatment and Disposal Data Quality objectives document. This combination of selective process testing and analyses to confirm historical predictions allows extrapolation of process testing results to other waste tanks.

The strategy must be applied in an iterative manner to work most effectively. Initially, a few tanks containing waste types with high concentrations of key analytes (or other parameters that limit processing capability) will be sampled and tests performed. Success of the process tests combined with the variability of process test results will dictate how much additional testing on other waste samples is required to provide high confidence that a robust process will result. This document identifies 25
\end{abstract}


primary tanks and additional secondary tanks that provide a good representation of the waste types of interest. This list represents the best estimate of the waste types needed for process testing, based on current knowledge of the waste. Waste samples from the primary tanks will be tested, with each set of test results used to refine the requirements for additional sampling. It is recognized that in some cases it will be difficult to obtain waste from the recommended tank. Waste from a similar tank will be acceptable for initial process testing. 
WHC-SD-WM-TA-154

Revision 0

\section{CONTENTS}

1.0 STRATEGY OVERVIEW ..................... 1

1.1 SAMPLING STRATEGY FOR SINGLE-SHELL TANKS $\ldots \ldots \ldots$

1.2 SAMPLING STRATEGY FOR DOUBLE-SHELL TANKS ......... 4

1.3 CONCLUSIONS AND RECOMMENDATIONS . . . . ........ 4



2.1 TANK WASTE REMEDIATION SYSTEM . . . . . . . . 7

2.2 NEED FOR SAMPLING AND TESTING OF TANK WASTES ...... 7

2.3 FUNCTIONS AND SCOPE OF TANK WASTE CHARACTERIZATION ..... 8

2.3.1 Description of Tanks and Tank Waste ....... 8

2.3.2 Historical Characterization Methods . . . . ... 8

2.3 .3 Tank Sampling ............... 9

2.3.4 Characterization Plans and Reports........ 10

2.3.5 Data Quality Objectives ............ 10

3.0 DISCUSSION OF BASIS FOR WASTE SAMPLING STRATEGY . . . . . . . 13

3.1 BASES AND ASSUMPTIONS . ....................... 13

3.2 ELEMENTS OF NEW SAMPLING STRATEGY ............ 14

3.2.1 Sampling Strategies for Single-Shell Tank Waste .... 14

3.2.2 Sampling Strategies for Double-Shell Tank Wastes . . . 23

3.3 NUMBER OF SAMPLES REQUIRED FROM EACH TANK ......... 25

3.4 ADVANTAGES TO THE PROPOSED TANK SAMPLING STRATEGY . . . . . 26

3.5 QUALITY ASSURANCE REQUIREMENTS ............. 27

4.0 REFERENCES . . . . . . . . . . . . . . . . . . . . 29

APPENDIX

A WASTE DISPOSAL TANK SAMPLING NEEDS ............ A-1

\section{LIST OF TABLES}

1. Recommended List of Single-Shell Tanks to Sample for Disposal Purposes................. . . 15

2. Application of SORWT Model to Classification of Selected Single-Shell Tanks............... 21

3. Recommended List of Double-Shell Tanks to Sample for Disposal Purposes . . . . . . . . . . . . . . . 
WHC-SD-WM-TA- 154

Revision 0

\section{LIST OF TERMS}

$\begin{array}{ll}\text { ANOVA } & \text { Analysis-of-Variance } \\ \text { CC } & \text { Complexed concentrate } \\ \text { DN } & \text { Dilute noncomplexed } \\ \text { DSSF } & \text { Double-Shell Slurry Feed } \\ \text { DNFSB } & \text { Defense Nuclear Facilities Safety Board } \\ \text { DOE } & \text { U.S. Department of Energy } \\ \text { DQO } & \text { Data Quality objectives } \\ \text { DST } & \text { Double-shell tank } \\ \text { HLW } & \text { High-level waste } \\ \text { ITS } & \text { In-Tank Solidification } \\ \text { LLW } & \text { Low-level waste } \\ \text { NCAW } & \text { Neutralized Current Acid Waste } \\ \text { NCRW } & \text { Neutralized Cladding Removal Waste } \\ \text { PFP } & \text { Plutonium Finishing Plant } \\ \text { PNL } & \text { Pacific Northwest Laboratory } \\ \text { PUREX } & \text { Plutonium-Uranium Extraction } \\ \text { REDOX } & \text { Reduction oxidation } \\ \text { SORWT } & \text { Sort on Radioactive Waste Type } \\ \text { SST } & \text { Single-shell tank } \\ \text { TRU } & \text { Transuranic } \\ \text { TWRS } & \text { Tank Waste Remediation System } \\ \text { USQ } & \text { Unreviewed Safety Question } \\ \text { WHC } & \text { Westinghouse Hanford Company } \\ \text { WSTRS } & \text { Waste Status and Transaction Record Summary }\end{array}$


WHC-SD-WM-TA-154

Revision 0

\section{STRATEGY FOR SAMPLING HANFORD SITE TANK WASTES FOR DEVELOPMENT OF DISPOSAL TECHNOLOGY}

\subsection{STRATEGY OVERVIEW}

The U.S. Department of Energy (DOE) recently announced a decision to retrieve all single-shell tank (SST) and double-shell tank (DST) waste at the Hanford Site and process the retrieved waste for final disposal. This decision prompted re-examination of preretrieval waste sampling and subsequent characterization (i.e., chemical and physical property measurements and process development testing) needs for disposal purposes. Specific end user data requirements for preretrieval characterization information in the areas of pretreatment and vitrification of both the high- and low-level fractions have been used in this study.

This study presents a proposed strategy for sampling SST and DST waste to provide information necessary to satisfactorily support the Tank Waste Remediation System (TWRS) disposal mission. The tank sampling and process testing strategy provides data and information needed to satisfactorily complete Hanford Federal Facility Agreement and Consent Order (Tri-Party Agreement) (Ecology et a1. 1994) milestone M-50-03, "Complete Evaluation of Enhanced Sludge Washing to Determine Whether Advanced Sludge Processes are Required." Also, this document is the deliverable report identified in Commitment 1.23 in Recommendation 93-5 Implementation Plan (DOE 1994) to identify "Bounding Tanks" for disposal. The implementation plan was prepared in response to recommendations of the Defense Nuclear Facilities Safety Board (DNFSB 1993). Bounding tanks are those prototypical of a particular historical waste type, and are judged from historical data to contain bounding inventories or concentrations of key constituents such as aluminum, chromium, and phosphate.

The baseline approach (Jensen 1994) for the TWRS is to wash (pretreat) high-level waste (HLW) sludges using enhanced methods (e.g., leaching with $\mathrm{NaOH}$ ) to remove certain key components from the sludge (e.g., aluminum, chromium, phosphate, etc.). Removal of significant amounts of these components will reduce the volume of $H L W$ glass that results from vitrification of the sludges. If enhanced sludge washing is ineffective, a larger volume of HLW glass will be produced, with associated increased operational and disposal costs. The response to milestone M-50-03 will document if enhanced sludge washing is judged to be technically effective. If not, some alternative course of action may be desirable such as use of extensive separations techniques to reduce the volume of HLW feed to the vitrification process.

Tank samples will provide material for TWRS process development testing. The information gained will be used to define the key constituent species in the sludge that govern the design parameters for the pretreatment and vitrification processes. Primary analyses of samples will occur during process development testing studies. Selective analysis of some tank-samples may also be used to supplement and confirm ongoing historical evaluations of 
WHC-SD-WM-TA- 154

Revision 0

tank contents to better understand individual tank inventories and physical and chemical properties of the waste.

The strategy for analyzing selected tank samples to determine important chemical and physical properties is provided in the recently issued Interim Data Quality Objectives for Waste Pretreatment and Vitrification (Kupfer et a). 1994). This report will be updated to define the minimum analysis needed to supplement historical information and allow extrapolation of process test results to other tanks.

Another important function of the TWRS is to identify and resolve any safety issues associated both with continued interim storage of wastes in the SSTS and DSTs and with eventual retrieval and processing of such wastes for disposal. The tank waste sampling strategy described in this report is for waste disposal purposes only. Thus, the tank sampling strategy presented here in may not necessarily meet all the needs involved in identification and resolution of tank waste safety issues. The technical basis for tank waste characterization to identify and resolve tank waste safety issues was addressed in a series of issued Data Quality Objectives (DQOS).

\subsection{SAMPLING STRATEGY FOR SINGLE-SHELL TANKS}

A phased, iterative approach is used to perform initial sampling and to define additional sampling requirements. Current limited knowledge of tank contents prevent exact specification of bounding waste types and analyte concentrations. However, from historical data, sets of tanks can be selected that likely represent bounding conditions. In the first sampling phase, core samples will be taken from 25 tanks expected to span a wide range of waste pretreatment and vitrification feeds. Auger samples from another six SSTs will also be taken in the first phase. In a later sampling phase, core samples will be taken from additional SSTs, currentiy expected to number 14 . However, data and results from process testing with waste samples taken in the first sampling phase will be considered in final selection of the additional SSTs to core sample.

Waste from 12 other SSTs sampled since 1989 already have been characterized or are archived. Process development data obtained with wastes from those 12 SSTs will provide additional information to support TWRS disposal decisions. Results of work performed on the previous 12 samples combined with test results for all new samples are expected to provide sufficient information to meet end user needs for preretrieval characterization data for disposal purposes.

The following selection criteria were employed for defining the SST sampling list.

- Tanks with overall high waste volumes were preferred (both sludges and salt cakes).

- For tanks that contain both salt cake and sludge, tanks with higher sludge contents were identified as more desirable. 
- Tanks with single waste types or uncomplicated process histories were identified as more desirable.

- Similarities in composition among tanks is expected to be observed. The Sort on Radioactive Waste Type (SORWT) (Hill and Simpson 1994) grouping scheme was used to ensure that all major waste types are represented and to determine candidate tanks within the same group. The SORWT scheme groups tanks on the basis of the type(s) of waste introduced into the tanks and their subsequent process history.

- Representation from each of the various evaporation processes that generated salt cake was sought.

- For tanks that have been previously sampled and where substantial characterization data exist, those data sets will be used to their fullest extent. With few exceptions, revisiting previously sampled/analyzed tanks was avoided.

- Choices also were influenced by the quantity and concentrations of components known to limit glass waste loading (i.e., HLW glass volume), such as chromium; suspected to be in the tank.

The 45 tanks tentatively selected for first and second phase core sampling and auger sampling along with the 12 tanks previously sampled and characterized (and/or archived) have the following characteristics:

- The tanks contain about 65 vol\% of the total SST sludge inventory.

- The tanks contain about 37 vol\% of the total SST salt cake inventory and are representative of all the evaporation processes that generated salt cake.

- The selected tanks include 24 of the 30 different SST waste groups identified by the SORWT model. These groups encompass approximately 93 percent of the total waste volume, 85 percent of the total sludge volume, and 97 percent of the total salt cake volume.

- The tanks contain, according to Agnew 1994a and normalized Track Radioactive Components (TRAC) computer code (Boomer et al. 1993) predictions, large inventories of nonradioactive constituents (e.g., aluminum, chromium, phosphate) known to be highly important to development of viable pretreatment and/or vitrification technology.

The sampling strategy emphasizes the need to develop pretreatment process technology data for sludges. Sludges, because of their different origins and compositions, are central to the development of pretreatment and vitrification technology. This strategy also includes sampling a representative amount of salt cake. All salt cake in SSTs contains relatively large concentrations of water soluble $\mathrm{NaNO}_{3}, \mathrm{NaNO}_{2}, \mathrm{NaOH}$, and $\mathrm{Na}_{2} \mathrm{CO}_{3}$, and smaller amounts of other sodium compounds (e.g., $\mathrm{NaAlO}_{2}, \mathrm{Na}_{2} \mathrm{SO}_{4}$, and $\mathrm{Na}_{3} \mathrm{PO}$ ). The important radionuclides present in salt cake are ${ }^{99} \mathrm{Tc}$ and ${ }^{\mathrm{TS}} \mathrm{Cs}$. Retrieval of the stored SST waste will result in the alkaline dissolution of the salt cake. The 
WHC-SD-WM-TA-154

Revision 0

general uniformity of the dissolved salt cake makes the development of acceptable pretreatment and vitrification technology much easier than for sludges. Pretreatment will remove constituents necessary to leave the remainder of the waste solution as feed to LLW vitrification. Present pretreatment plans are to remove only ${ }^{137} \mathrm{CS}$ and possibly organic complexants from dissolved salt cake.

Sampling and testing of wastes in only a subset of the SSTs versus all 149 SSTs is expected to result in significant cost savings. Cost reductions stem from reduction of the number of samples to be taken and al so from a reduction in the number of analyses required. Properties of wastes in the remaining SSTs can be determined, as needed, by various other methods, either singly or in combination. These methods include using historical fill records and predictive modeling using existing analytical data. In some cases, less expensive sampling methods such as auger sampling and/or bulk (grab) sampling techniques may be used to support or replace core sampling.

\subsection{SAMPLING STRATEGY FOR DOUBLE-SHELL TANKS}

The sampling strategy for DST wastes involves taking full waste-depth cores from only 12 of the 28 DSTs. For DST waste, the use of grab sampling or a combination of grab sampling and core sampling, may be appropriate rather than core sampling alone. These 12 DSTs have the following characteristics:

- The tanks contain about 85 vol\% of the total DST sludge inventory.

- The tanks contain about 43 vol\% of the total DST supernatant liquid inventory.

- The tanks encompass all the six major types of DST wastes (i.e., complexant concentrate, double-shell slurry feed, neutralized current acid waste, neutralized cladding removal waste, Plutonium Finishing Plant waste, and dilute noncomplexed waste).

- The tanks contain estimated large inventories of components (e.g., chromium, aluminum, phosphate, organic carbon, transuranics) known to impact the performance of pretreatment process and/or vitrification technology.

Information from DST samples already taken can be used to supplement data obtained from the 12 recommended DSTs.

\subsection{CONCLUSIONS AND RECOMMENDATIONS}

The proposed tank waste sampling strategy in support of the TWRS is in full accord with stated requirements of the DQO process and with relevant parts of the recently renegotiated Tri-Party Agreement. The revised waste sampling and analysis strategy proposed in this report has considerable technical and economic merit. Use of a phased, iterative approach will allow proper allocation of 1 imited resources and will result in a timely resolution to fulfilling needs for the process technology database. 
Several follow-on actions are recommended:

- The results of the early sample analyses and process testing should be evaluated and utilized to modify the number and identity of tanks for subsequent sampling. Such evaluations should consider use of the historical modeling bases presently being evaluated by Los Alamos National Laboratory, Ogden Environmental, and Hanford Site personnel as a means of identifying those tanks that contain key elements of importance to pretreatment and vitrification processes.

- A critique of ongoing historical modelling efforts should be examined by present and previous Hanford Site personnel who have extensive long-term experience and detailed knowledge of process history.

- The SORWT criteria should be used to evaluate and select alternate tanks for sampling should technical or programmatic response prevent timely acquisition of samples from the tanks identified in this document.

- Sampling and analytical requirements to support tank waste retrieval processes need to be established using the DQO process. These requirements must then be incorporated into the tank sampling strategy to support TWRS disposal.

- Studies should be completed to evaluate techniques less expensive than core sampling for obtaining representative waste materials for characterization and process evaluation tests, e.g., enhanced grab and auger sampling techniques.

- An optimum scheme for dividing proposed sample characterization tasks between the TWRS Characterization Program and both onsite and offsite process development laboratories to provide rapid and accurate results should be defined. 
WHC-SD-WM-TA-154

Revision 0

This page intentionally left blank. 
WHC-SD-WM-TA-154

Revision 0

\subsection{BACKGROUND}

\subsection{TANK WASTE REMEDIATION SYSTEM}

At the DOE Hanford Site, radioactive liquid and solid wastes are currently stored in 149 SSTs and 28 DSTS. DOE recentiy announced a decision (Ecology et al. 1994) to retrieve, for eventual final disposal, all the wastes from both the SSTs and DSTs. In response to this decision, the TWRS program was developed and documented (Johnson et al. 1993). The current technical strategy for accomplishing TWRS objectives also has been formulated (Wodrich 1994).

Principal functions of the TWRS include resolution of safety issues associated with interim storage of tank waste, tank waste characterization, waste retrieval, pretreatment of retrieved wastes to produce and/or separate low-level waste (LLW) and HLW fractions, and vitrification of the LLW and HLW fractions. An important objective of the TWRS is to separate the retrieved wastes into a relatively small volume of HLW and a larger volume of LLW. Vitrified LLW will eventually be disposed of at the Hanford Site in a nearsurface facility while vitrified HLW will be disposed of in a deep geologic repository.

\subsection{NEED FOR SAMPLING AND TESTING OF TANK WASTES}

Tank sampling and testing of sampled wastes are needed to make key decisions necessary to support the TWRS disposal mission. Information on waste physical and chemical properties will help define the strategy for retrieval of tank waste, and the scope of waste pretreatment activities needed to provide suitable feed for waste vitrification. Of particular significance is a decision to be made by March 1998 that was established as part of the recently renegotiated Tri-Party Agreement (Ecology et al. 1994). This decision (Milestone M-50-03) will define the extent of waste pretreatment processes that must be utilized to prepare vitrification feed. The baseline approach (Jensen 1994) for the TWRS is to wash (pretreat) HLW sludges using enhanced methods (e.g., leaching with $\mathrm{NaOH}$ ) to remove certain key components from the sludge such as aluminum, chromium, phosphate, etc. Removal of significant amounts of these components will reduce the volume of HLW glass that results from vitrification of the sludges. If enhanced sludge washing is ineffective, a larger volume of HLW glass will result, with associated increased operational and disposal costs. The response to milestone M-50-03 will document if enhanced sludge washing is judged to be technically effective. If not, an additional course of action may be desirable to reduce the volume of HLW feed to the vitrification process (Jensen 1994).

The waste from any particular SST or DST certainly can be conveniently sampled and analyzed after retrieval to provide much more accurate and reliable needed information than can ever be obtained by analysis of one or two core samples from the tank. Thus, preretrieval sampling and analys is for disposal purposes should be limited to that essential to develop needed

retrieval, pretreatment, and vitrification technology. It is clear that some 
WHC-SD-WM-TA-154

Revision 0

minimum amount of preretrieval core sampling and analys is of tank wastes is needed. Certain key pretreatment and vitrification technologies (e.g., sludge leaching, sludge dissolution, glass formulation development) cannot be developed without knowing the bounding chemical constituents and radionuclides in actual waste liquids and solids.

\subsection{FUNCTIONS AND SCOPE OF TANK WASTE CHARACTERIZATION}

\subsubsection{Description of Tanks and Tank Waste}

Between 1943 and 1964,149 SSTs were built at the Hanford Site. These tanks were used to store radioactive waste generated at the Hanford Site. The 149 SSTs, located in 12 separate areas (tank farms) in the 200 East Area and 200 West Area, are currently estimated to contain $89,000 \mathrm{~m}^{3}$ of salt cake, $48,000 \mathrm{~m}^{3}$ of sludge, and $2,300 \mathrm{~m}^{3}$ of alkaline liquid.

Between 1971 and 1986, 28 DSTs were constructed at the Hanford Site. Each of the DSTs was designed to contain, nominally, 4,000 $\mathrm{m}^{3}$ of waste. One of the DST tank farms ( 3 tanks) is located in the 200 West Area; the remaining 5 DST farms (25 tanks) are located in the 200 East area. As of January 1994, the 28 DSTs contained about $88,000 \mathrm{~m}^{3}$ of alkaline liquid and about $10,000 \mathrm{~m}^{3}$ of solid waste. A detailed description and status of Hanford tanks and tank waste are provided in Hanlon 1994. Additional information concerning the different types of wastes stored in the DSTs is presented in Chapter 3.0 .

\subsubsection{Historical Characterization Methods}

The various plans for final disposal of the wastes in the SSTs and DSTS, which have evolved over a decade or more, have all stressed the need to characterize the wastes. The TRAC computer code (Jungfleisch 1984) was an important initial step in characterizing wastes in both SSTs and DSTs. Input data to the TRAC code were derived from several sources: historical records of fuel irradiation conditions, fuel reprocessing chemical flowsheets, waste volumes, waste transfer routes and final destinations, and essential chemical purchases. Input data were coupled with computer code calculations of the radionuclide content of irradiated fuel at the time of reactor discharge and ORIGEN2 (Oak Ridge Isotope Generation and Depletion) code (Croft 1980)

calculations of radionuclide decay. The final output of the TRAC code was a listing (as of 1984) of the quantities of 65 radionuclides and 30 nonradioactive chemicals in each SST and DST. The TRAC code predictions for nonradioactive chemicals were later adjusted or "normalized" (Boomer et al. 1993) to ensure that the total chemical inventories in all of the SSTs matched those in the Hanford Defense Waste Environmental Impact Statement (DOE 1987).

For various reasons (e.g., incomplete or faulty historical input data, incorrect assumptions concerning solubility of various waste components) the TRAC code predictions are quite uncertain. This has prompted a recent effort to expand the process to utilize historical tank content estimates as an important element in providing a basis for TWRS waste disposal decisions. 
Los Alamos National Laboratory scientists, in association with personnel from ICF Kaiser Hanford Company, Westinghouse Hanford Company, and Ogden Environmental, as initiated by the Characterization Program Office in the TWRS, are currently developing what is termed the Historical Tank Content Estimate documents. These documents (four volumes) are being prepared from three separate elements: the Waste Status and Transaction Record Summary (WSTRS) reports (Agnew 1994b, Agnew 1994c), the Tank Layer Models (Agnew 1994d, Agnew 1994e), and the Defined Waste document (Agnew 1994a). The WSTRS is prepared from existing historical records such as the TRAC code transactions file and information in Anderson (1990) and is verified, as far as possible, from additional historical records. The WSTRS data concerning waste volumes and solids level measurements are used to provide a Tank Layer Model of the type and amounts of sludge and salt cake predicted to be in each tank. The third element, the Defined Waste List, is generated from historical process chemical flowsheet and essential materials purchase records.

Combination of the WSTRS, Tank Layer Model, and Defined Waste List information provides an estimate of the types and inventories of waste components in each SST and DST and a framework for understanding and interpreting sample results. Estimates thus obtained will be compared to waste composition and inventory data defined by analysis of actual waste samples when such analytical data become available. Two of the four scheduled Historical Tank Content Estimate reports were recently issued (Brevick et al. 1994a, Brevick et a1. 1994b). The tank modelling efforts should be reviewed by present and former Hanford Site personnel who have long-term experience and extensive knowledge of process history.

\subsubsection{Tank Sampling}

In addition to characterization information obtained from known purchase records, process knowledge, and tank transfer records, significant knowledge of tank waste has been obtained over the years through tank grab samples, direct process sampling, and process campaign reports (e.g., 242-A and 242-S Evaporator runs).

Concomitant with the development of the TRAC code, much effort was expended in the late 1970 s and early 1980s to design and manufacture equipment to take full-depth core samples from SSTs and DSTs. This effort resulted in construction of the first core sample truck and associated equipment

(Bell 1993). Currently this equipment is routinely used to take core samples from both SSTs and DSTs. Depending on the depth of waste in a particular tank, core samples up to $11.5-\mathrm{m}$ long $(2248-\mathrm{cm}$. long segments) can be taken. The "push type" equipment for taking core samples has recently been supplemented with new rotary drilling equipment. The new machinery will facilitate acquisition of core samples from certain SSTs that contain "hard pan-type" solids.

Procedures (Winters et al. 1990, Bell 1993) are currently in place to do the following:

- Receive up to $2248-\mathrm{cm}$ long core segments.

- Remove solid and liquid wastes from individual core sample segments. 
WHC-SD-WM-TA-154

Revision 0

- Sample solid and liquid wastes in each individual core segment.

- Composite wastes from several core sample segments.

- Sample composites of core sample segments.

Procedures are also in place for auger and grab sampling methods.

Analytical procedures also are in place for determining the radionuclide content of individual samples, subsamples, and composite samples as well as the concentration of most inorganic cations and anions. Specialized equipment and procedures for quantifying various organic materials in certain wastes a) so have been developed and applied. Considerable capability al so exists for determining the physical properties of samples of solid wastes (Bell 1993).

\subsubsection{Characterization Plans and Reports}

A detailed plan for characterization of SST and DST wastes was first published in 1990 (Winters et al. 1990). The plan was revised in 1993 and in 1994 (Be11 1993, 1994). The updated characterization planning documents focus on Fiscal Year 1993 and outyear plans for sampling wastes in several important SSTs and DSTs. Various methods for sampling waste tanks and laboratory operations with the samples are described. A Quality Assurance Project Plan and a bibliography to various important waste characterization documents are also provided.

The recently amended Tri-Party Agreement, Amendment 4 (Ecology et al. 1994), establishes several new enforceable milestones for characterization of wastes in SSTs and DSTs. Tank characterization plans must be prepared before the tank sampling event. Tank characterization reports will be provided by 1999 for a 11177 Hanford Site underground tanks. The scope of the reports will include information from tank waste samples as well as historical records of tank contents, flowsheets, etc.

\subsubsection{Data Quality Objectives}

The requirements for characterization of tank wastes are being determined by a DQO process (Babad et a1. 1994). The Tri-Party Agreement (Ecology et a1. 1994) requires that the DQO process be used to support the completion of the required tank characterization reports. The DQO process will result in identification and integration of data requirements needed for streamlined tank characterization efforts.

DQO documents are being prepared for the following functional areas of the TWRS Program:

- Waste Tanks Safety Programs

- Waste Compatibility (Operations)

- Retrieval 
WHC-SD-WM-TA-154

Revision 0

- Pretreatment

- HLW and LLW Immobilization.

This approach is consistent with recommendations made by the DNFSB (DNFSB 1993) concerning the scope and objectives of the TWRS waste characterization program particularly as they relate to certain SSTs.

A DQO document that will evaluate characterization needs to support development of processes for retrieval of tank waste is presently being prepared. Data quality objectives are already in place that address tank waste safety requirements during waste storage. An interim DQO document that addresses characterization needs to support waste pretreatment, $H L W$ vitrification, and LLW vitrification was recently issued (Kupfer et a1. 1994). Kupfer et al. 1994 also describes needed sampling events that must occur before Fiscal Year 1998 to make key decisions on the TWRS disposal strategy. The basis for selection of the tanks listed in Kupfer et al. 1994 is examined in more detail in this report. 
WHC-SD-WM-TA-154

Revision 0

This page intentionally left blank. 


\subsection{DISCUSSION OF BASIS FOR WASTE SAMPLING STRATEGY}

Information necessary to define the scope of waste pretreatment and vitrification processes to support the TWRS disposal strategy will be gained by obtaining an appropriate selection of tank waste samples and testing the samples to define process parameters. It is highly important that samples are provided in a timely manner to ensure completion of the Tri-Party Agreement milestone M-50-03 (Ecology et a1. 1994) by March 1998 (see Section 2.2).

It is important to obtain a cross-section of samples that provides adequate representation of the bulk waste. In addition, wastes that represent the extreme conditions, or bound the waste properties, are considered critical for defining the scope of the disposal functions, i.e., establish the viability of the process flowsheet and equipment. A proper selection of tanks to sample will allow determination of the technical information needed with a minimum number of samples.

\subsection{BASES AND ASSUMPTIONS}

The proposed strategy for characterizing wastes for disposal in the 149 SSTs and 28 DSTs derives from the following bases and assumptions.

1. All SST and DST wastes will be retrieved for final disposal.

2. All SST and DST wastes can be classified into a relatively small number of types and compositions. Knowledge of the types of wastes added to the tanks will allow grouping of tanks containing like wastes.

3. Not all tanks in the same group of SSTs or DSTs need to be core sampled before retrieval. Characterization information derived from carefully selected tanks will provide sufficient data to perform satisfactory pretreatment and disposal of waste in all the tanks in a particular group.

4. Development of certain key pretreatment and vitrification technologies is highly dependent on knowledge of the chemical properties of water-insoluble sludges.

5. It is not necessary to determine the chemical composition of all individual core segments or subsegments to obtain sufficient data to develop technology for pretreatment and vitrification of SST wastes.

6. Equipment and procedures already in place or already scheduled to be acquired or developed in the future will be used to take core samples from a selected number of SSTs and DSTs. 
WHC-SD-WM-TA-154

Revision 0

7. Analytical instrumentation, procedures, and protocols, including DQOS, already in place or already scheduled for development will be used to determine selected chemical and physical properties of individual SST and DST core sample solid strata, segments, and composites.

8. The proposed strategy for characterizing SST and DST wastes for disposal purposes is in full accord with the relevant parts of the Tri-Party Agreement (Ecology et al. 1994).

\subsection{ELEMENTS OF NEW SAMPLING STRATEGY}

The tank selection method is based on the fact that wastes in all SSTs and DSTs can be classified into small groups with similar chemical composition and physical and chemical properties. Preliminary considerations indicate there are at least three reasonable bases for classifying SST and DST wastes:

- Inventory of wastes, primarily sludges

- Type(s) of waste introduced into each tank based on historical records

- Inventory of key waste constituents.

As evidenced by the ensuing discussion, these bases, especially when considered collectively, appear very useful for classifying the contents of the SSTs and DSTs.

\subsubsection{Sampling Strategies for Single-Shell Tank Waste}

In the proposed sampling strategy, core samples will be taken from each of 39 selected SSTs. In addition, auger samples will be taken from six SSTs. Auger samples are less expensive to acquire than core samples and can be used if the tank contains $\leq 51 \mathrm{~cm}$ of waste. A phased iterative approach will be used for SST waste sampling (see Section 3.2.1.3). Table 1 shows the preliminary list of the 45 SSTs recommended for sampling. If, for some reason, one or more of the recommended tanks cannot be sampled, then carefully selected alternative tanks should be chosen for sampling using the selection criteria stated in Section 3.2.1.1. 
WHC-SD-WM-TA-154

Revision 0

Table 1. Recommended List of Single-Shell Tanks to Sample for Disposal Purposes. (2 sheets)

\begin{tabular}{|c|c|c|c|c|c|c|c|}
\hline \multirow{2}{*}{$\begin{array}{l}\text { Group } \\
\text { (SORWT) }\end{array}$} & \multirow[t]{2}{*}{ Tank } & \multicolumn{2}{|r|}{ Phase 1} & \multicolumn{2}{|r|}{ Phase II } & \multicolumn{2}{|r|}{ Auger } \\
\hline & & $\begin{array}{c}m^{3} \\
\text { sludge } \\
\end{array}$ & $\mathrm{salt}^{3}$ cake & $\begin{array}{c}m^{3} \\
\text { sludge }\end{array}$ & $\mathrm{m}^{3}$ & $\begin{array}{c}m^{3} \\
\text { sludge } \\
\end{array}$ & $\begin{array}{c}\mathrm{m}^{3} \\
\text { Salt } \text { cake }\end{array}$ \\
\hline 9 & $A-101$ & 11 & 3,590 & & & & \\
\hline 30 & A- 106 & 473 & 0 & & & & \\
\hline 9 & $A X-101$ & & & 11 & 2,820 & & \\
\hline 18 & $B-103$ & 223 & 269 & & & & \\
\hline 30 & B-104 & & & 1,140 & 1,010 & & \\
\hline 12 & $B-107$ & 621 & 0 & & & & \\
\hline 4 & $B X-101$ & & & & & 159 & 0 \\
\hline 4 & $B X-102$ & 363 & & & & & \\
\hline 4 & $B X-106$ & & & & & 117 & 0 \\
\hline 4 & $B X-109$ & 731 & 0 & & & & \\
\hline 3 & $B Y-104$ & 151 & 1,385 & & & & \\
\hline 3 & $B Y-105$ & 166 & 1,737 & & & & \\
\hline 3 & $B Y-106$ & & & 360 & 2,070 & & \\
\hline 3 & $B Y-108$ & & & 583 & 280 & & \\
\hline 21 & BY- 109 & & & 314 & 1,290 & & \\
\hline 30 & $c-102$ & 1,600 & 0 & & & & \\
\hline 23 & $c-103$ & 235 & 0 & & & & \\
\hline 30 & $c-104$ & 1,120 & 0 & & & & \\
\hline 30 & $c-105$ & 568 & 0 & & & & \\
\hline 23 & $c-106$ & 746 & 0 & & & & \\
\hline 30 & $c-107$ & & & 1,040 & 0 & & \\
\hline 1 & $s-101$ & 924 & 647 & & & & \\
\hline 1 & $s-107$ & 1,110 & 261 & & & & \\
\hline 1 & $s-110$ & & & 496 & 980 & & \\
\hline 1 & $s-111$ & & & 526 & 1,890 & & \\
\hline 1 & $5 x-101$ & 424 & 1,300 & & & & \\
\hline 1 & $5 x-104$ & & & 515 & 1,810 & & \\
\hline
\end{tabular}


Table 1. Recommended List of Single-Shell Tanks to Sample for Disposal Purposes. (2 sheets)

\begin{tabular}{|c|c|c|c|c|c|c|c|}
\hline \multirow{2}{*}{$\begin{array}{l}\text { Group } \\
\text { (SORWT) }\end{array}$} & \multirow[t]{2}{*}{ Tank } & \multicolumn{2}{|r|}{ Phase I } & \multicolumn{2}{|r|}{ Phase II } & \multicolumn{2}{|r|}{ Auger } \\
\hline & & $\begin{array}{c}\mathrm{m}^{3} \\
\text { sludge } \\
\end{array}$ & $\begin{array}{c}\mathrm{m}^{3} \\
\text { Salt }\end{array}$ & $\begin{array}{c}\mathrm{m}^{3} \\
\text { sludge }\end{array}$ & $\begin{array}{c}m^{3} \\
\text { Salt }\end{array}$ & $\begin{array}{c}\mathrm{m}^{3} \\
\text { sludge }\end{array}$ & $\begin{array}{c}\mathrm{m}^{3} \\
\text { Salt }\end{array}$ \\
\hline 6 & $5 x-108$ & 435 & 0 & & & & \\
\hline 6 & $5 x-109$ & & & 946 & 0 & & \\
\hline 16 & $5 x-111$ & 473 & 0 & . & & & \\
\hline 6 & $s x-112$ & & & & & 348 & 0 \\
\hline 19 & $T-101$ & 390 & 0 & & & & \\
\hline 14 & $T-110$ & & & 1,420 & 0 & & \\
\hline 26 & $T X-103$ & 594 & 0 & & & & \\
\hline 1 & $T X-104$ & & & & & 0 & 242 \\
\hline 1 & $7 x-105$ & 0 & 2,305 & & & & \\
\hline 1 & $T X-107$ & & & & & & 132 \\
\hline 2 & $T x-116$ & 0 & 2,388 & & & & \\
\hline 2 & $T x-117$ & & & 0 & 2,369 & & \\
\hline 27 & $T Y-103$ & & & 613 & 0 & & \\
\hline 25 & $T Y-105$ & 874 & 0 & & & & \\
\hline 6 & $u-101$ & & & & & 83 & 0 \\
\hline 7 & $U-103$ & 121 & 1,650 & & & & \\
\hline 10 & $U-109$ & 182 & . 1,570 & & & & \\
\hline 7 & $u-111$ & & & 98 & 1,147 & & \\
\hline & Totals & 12,540 & 17,100 & 8,060 & 15,670 & 707 & 374 \\
\hline
\end{tabular}

Wastes in 33 of the 149 SSTs were core sampled and partially characterized in the period 1986 to 1993. The strategy for characterization of SST waste to support disposal needs includes utilization of data obtained from analysis of some of these previously sampled wastes. Characterization of wastes in some of the 33 previously sampled SSTs included analys is of solid core composite material and water washes. The data thus obtained relate directly to development of technology for vitrification of the water-washed sludge. However, other waste pretreatment process development tests, e.g., $\mathrm{NaOH}$ and $\mathrm{HNO}_{3}$ leaching dissolution tests with the water-washed solids, were performed on only five of the 33 sampled SSTs (241-B-110, 241-B-201, 
241-C-109, 241-C-112 and 241-U-110) (Lumetta and Rapko 1994). Data from these expanded leaching and dissolution tests are of critical importance in developing technology for extensive pretreatment of water-washed SST siudges.

Archived core composite material is also available for seven of the 33 SSTs (241-B-111, 241-B-202, 241-BX-107, 241-S-104, 241-T-104, 241-T-107, and 241-T-111). Further examination of the archived solid core composite material for these seven tanks as well as the five tanks examined by Lumetta and Rapko 1994 would extend the qualified characterization data to 57 SSTs.

Section 3.2.1.1 briefly lists the criteria used for selecting the SSTs (Table 1) for sampling. Section 3.2.1.2 describes the basis and rationale for each criterion and the degree to which each criterion is met.

3.2.1.1 Criteria Utilized for Selecting Single-Shell Tanks for Sampling. The following selection criteria were employed for defining the SST sampling list.

- Tanks with overall high volumes of both sludges and salt cakes were preferred.

- For tanks with both salt cake and sludges, the tanks with higher sludge contents were identified as more desirable.

- Tanks with single waste types or uncomplicated process histories were identified as more desirable.

- Similarities in composition and physical properties among tanks is expected to be observed. The SORWT grouping scheme was used as a basis to select tanks within the same group. The SORWT scheme groups tanks on the basis of the type(s) of waste originally introduced into the tanks.

- Representation from each of the various evaporation processes that produced salt cake was sought (e.g., 242-A, 242-B, 242-S, 242-T, In-Tank Solidification [ITS] evaporation processes, and self-boiling tanks) to provide an adequate database for developing technology for pretreatment of salt cake.

- Watch list designation was an influencing factor in the selection process.

- For tanks that have been previously sampled and where substantial characterization data exist, those data sets were used to their fullest extent. With few exceptions, revisiting previousiy sampled/analyzed tanks was avoided.

- Sampling and analysis of tanks was phased. Results of testing from key Phase I tanks could result in some modification or deletions to the secondary (Phase II) tanks. Wide coverage of the wastes to provide the broadest possible database was desired. In some cases, however, tanks that provided supplementary representative data were deferred in favor of tanks thought to provide bounding conditions. 
- Choices were also influenced by the quantity of components known to limit glass waste loading (i.e., HLW glass volume), such as chromium, suspected to be in a particular SST.

\subsubsection{Basis and Rationale for Single-Shell Tank Waste Sample Selection.}

Classification on Basis of Waste Inventory. A straightforward method for selecting SSTs for core sampling is on the basis of their inventory of sludge and salt cake. The baseline TWRS waste pretreatment process employs water and $\mathrm{NaOH}$ leaching of waste sludges before vitrification of the washed sludges. The volume of HLW glass that must be disposed of in a geologic repository in highly dependent upon the volume of sludge resulting from the washing operations. The cost of vitrification and disposal of the HLW is a key factor in the overall TWRS disposal mission costs.

The SSTs 1 isted in Table 1 contain about 45 vol\% of the total SST sludge inventory (Hanlon 1994). The selected 45 tanks along with the five previously characterized tanks (Lumetta and Rapko 1994) and the seven tanks with archived samples contain approximately 65 vol\% of the sludge inventory.

If sludge inventory were the only criterion used for selecting tanks for sampling, obtaining samples from only 50 tanks could encompass approximately 80 vol\% of the sludge in SSTs. However, those SSTs which contain 80 percent of the total sludge inventory do not contain wastes representative of all of the various types known to have been introduced into the 149 SSTs (Hanion 1994). Additionally, such tanks contain only 16 percent of the total salt cake. Table 1 was compiled to address these selection criteria also.

The general uniformity in the composition of salt cake makes development of acceptable pretreatment and vitrification technology much easier than it is for sludges. Therefore, it is considered more important to core sample SSTs that contain large inventories of sludge rather than large inventories of salt cake. However, representation from salt cake is important, e.g., to determine inventories of key analytes which can impact LLW glass volumes, to determine inventories of ${ }^{137} \mathrm{Cs}$ and test ${ }^{137} \mathrm{Cs}$ removal methods, and to determine physical properties that can impact the choice of salt cake retrieval techniques.

The 45 tanks in Table 1 contain about 37 vol\% of the total SST salt cake inventory. The selected 45 tanks also represent all of the various evaporation processes that produced the salt cake. Archived samples and other previously analyzed core samples do not increase the representation of salt cake. The potential number of required core samples was reduced where possible by selecting tanks that contain large volumes of both sludge and salt cake.

Classification of Single-Shell Tanks on Basis of Fill History. A second important way of classifying SSTs is to use historical fill data to sort the 149 SSTs into groups of tanks that contain the same type (or types) of wastes. Development of retrieval, pretreatment, and vitrification processes will require characterization and testing of a cross section of the various waste types. Several major chemical separations processes performed at the Hanford 
WHC-SD-WM-TA-154

Revision 0

Site from 1943 through 1987 are recognized as generating different types of wastes that were introduced into the SSTs:

- $\mathrm{BiPO}_{4}$ Process

- REDOX Process

- PUREX Process

- Metal Recovery (Tributyl Phosphate) Process

- Nickel Ferrocyanide Scavenging Process

- B Plant ${ }^{90} \mathrm{Sr}$ Recovery/Purification Process

- Waste Evaporation-Crystallization and In-Tank Solidification Processes

- Fuel Cladding Removal Processes.

Detailed chemical flowsheet and waste composition information for all of these processes are available in a number of sources (Anderson 1990, Swanson 1990, Cleveland 1970, Larowski 1955, Stevenson and Smith 1961).

A History of the 200 Area Tank Farms (Anderson 1990) is invaluable for classifying SSTs on the basis of their fill history. Anderson (1990) provides relatively complete historical data for the type and amount of each type of waste introduced into each SST.

Hill and Simpson (1994) recently used Anderson's report and a database to develop a model--SORWT--to separate SSTs into characteristic groups. By applying Analysis-of-Variance (ANOVA) methods, Hill and Simpson were able to confirm group effects are present. The SORWT model correctly reflects the fact that, during their active life, each of the SSTs received waste from several different chemical process operations but that underlying patterns from waste management activities exist and can be used to optimize the data gathering and assessment efforts.

The fundamental premise of the SORWT model is that SSTs that received the same waste types in the same approximate proportion and had a similar processing history will be more similar to one another than SSTs that received several different waste types in varying amounts and had a relatively unique process history. In addition, waste types that are largely liquid do not have as significant an effect on the character of the waste in the tank as solidforming waste types. Therefore, if the primary and secondary solid-forming waste types can be identified for each SST, the tanks can be grouped based on this criterion. Information about the character of the waste in the rest of the members in the group can be deduced from the information obtained by the analysis of the samples from the representative tank, or from a selected number of representative tanks. 
Considerable use of the SORWT model classification system was made in this report to select SSTs for core sampling and characterization. In particular, the SORWT tank groupings provided a basis for ensuring that the recommended list of SSTs (Table 1) to core sample contained solids representative of the entire spectrum of wastes present in the 149 SSTs. As noted in Table 2, at least one tank from 24 of the 30 SORWT model groupings is recommended for core sampling and characterization for disposal purposes.

The number of tanks in a SORWT group chosen for sampling was influenced by the total number of tanks with in that SORWT group, e.g., SORWT group I contains 22 tanks and a total of 10 tanks in that group were chosen for sampling. In addition, the number of tanks chosen for sampling within a SORWT group was increased somewhat if that group contained a high percentage of the total SST sludge volume. The SORWT groups not included in the list of 45 SSTs to sample have potentially minimal significance, i.e., they contain very small volumes of waste.

As previously stated, the composition of a waste within a SORWT group can be deduced from information contained from analys is of a representative tank within the group. Thus, from the information gained from the 45 samples (Table 1) and the 12 previously characterized and archived samples, the 24 SORWT groups represent approximately 93 percent of the total waste volume, 85 percent of the total sludge volume, and 97 percent of the total salt cake volume.

Classification of Single-Shell Tanks By Content of Key Analytes. A third way of classifying SSTs for sampling and characterization for disposal purposes is to select those tanks that are predicted to contain substantial amounts of the total inventory of certain key analytes.. Of particular importance to vitrification of washed sludges are the analytes aluminum, chromium, and phosphate. Waste loadings that can be satisfactorily achieved when washed sludges are vitrified are strongly dependent upon the concentration of aluminum, chromium, and phosphate in the washed sludge. Certain other analytes, e.g., bismuth, uranium, and barium, are important to performance of various pretreatment processes for removing certain radionuclides from alkaline salt cake solutions and, possibly, acid sludge solutions. Tables A-1 through A-4, Appendix A, list analytes considered of importance to pretreatment and vitrification of SST wastes.

The normalized TRAC code is currently the only available tool for predicting the amount of key analytes in all the SSTs. As noted earlier, in a cooperative effort, Los Alamos National Laboratory, ICF-Kaiser Hanford Company, and Ogden Environmental personnel are preparing Historical Tank Content Estimate documents. A primary purpose of these latter reports is to provide a tank-by-tank inventory of selected radioactive and non-radioactive waste constituents. Documentation is presently complete (Brevick 1994a, Brevick 1994b) for tanks in nine of the 12 SST farms, i.e., A, AX, B, BX, BY, $C, S, S X$, and $U$ farms. 
Table 2. Application of SORWT Model to Classification of Selected Single-Shell Tanks.

\begin{tabular}{|c|c|c|c|}
\hline \multicolumn{3}{|c|}{ SORWT Descriptions ${ }^{a, b}$} & \multirow[t]{2}{*}{ Selected SSTs in Each SORWT Category } \\
\hline $\begin{array}{c}\text { Group } \\
\text { No. }\end{array}$ & $\begin{array}{c}\text { Primary } \\
\text { Waste }\end{array}$ & $\begin{array}{c}\text { Secondary } \\
\text { Waste }\end{array}$ & \\
\hline $\begin{array}{l}I(22) \\
I I(10) \\
I I I(10) \\
I V(9) \\
V(8) \\
V I(7) \\
V I I(5) \\
V I I I(5) \\
I X(4) \\
X(4) \\
X I(4) \\
X I I(4) \\
X I I I(4) \\
X I V(3) \\
X V(3) \\
X V I(3) \\
X V I I(3) \\
X V I I I(3) \\
X I X(3) \\
X X(3) \\
X X I(2) \\
X X I I(2) \\
X X I I I(2) \\
X X I V(2) \\
X X V(2) \\
X X V I(2) \\
X X V I I(2) \\
X X V I I I(2) \\
X X I X(2) \\
X X X(14)\end{array}$ & $\begin{array}{l}R \\
\text { EB } \\
\text { TBP-F } \\
\text { TBP } \\
224 \\
R \\
\text { EB } \\
\text { TBP-F } \\
\text { DSSF. } \\
\text { EB } \\
\text { IC } \\
\text { IC } \\
\text { HS } \\
2 C \\
2 C \\
R \\
\text { YC } \\
\text { CW } \\
\text { CW } \\
\text { CW } \\
\text { TBP } \\
\text { EB } \\
\text { SRS } \\
\text { IC } \\
\text { TBP } \\
\text { TBP } \\
\text { TBP } \\
\text { CCPLX } \\
\text { R } \\
\text { UNGROUPED }\end{array}$ & $\begin{array}{l}\text { EB } \\
\text { IC } \\
\text { EB-ITS } \\
C W \\
\text { R } \\
\text { IC } \\
\text { NCPLX } \\
\text { CW } \\
\text { IBP } \\
\text { EB } \\
\text { 224 } \\
5-6 \\
\text { RIX } \\
\text { CW } \\
\text { EB } \\
\text { MIX } \\
\text { EB-ITS } \\
\text { IBP } \\
\text { ILUICE } \\
\text { EB-ITS } \\
\text { EB } \\
\text { IC-F } \\
\text { DSSF } \\
\text { DIA }\end{array}$ & 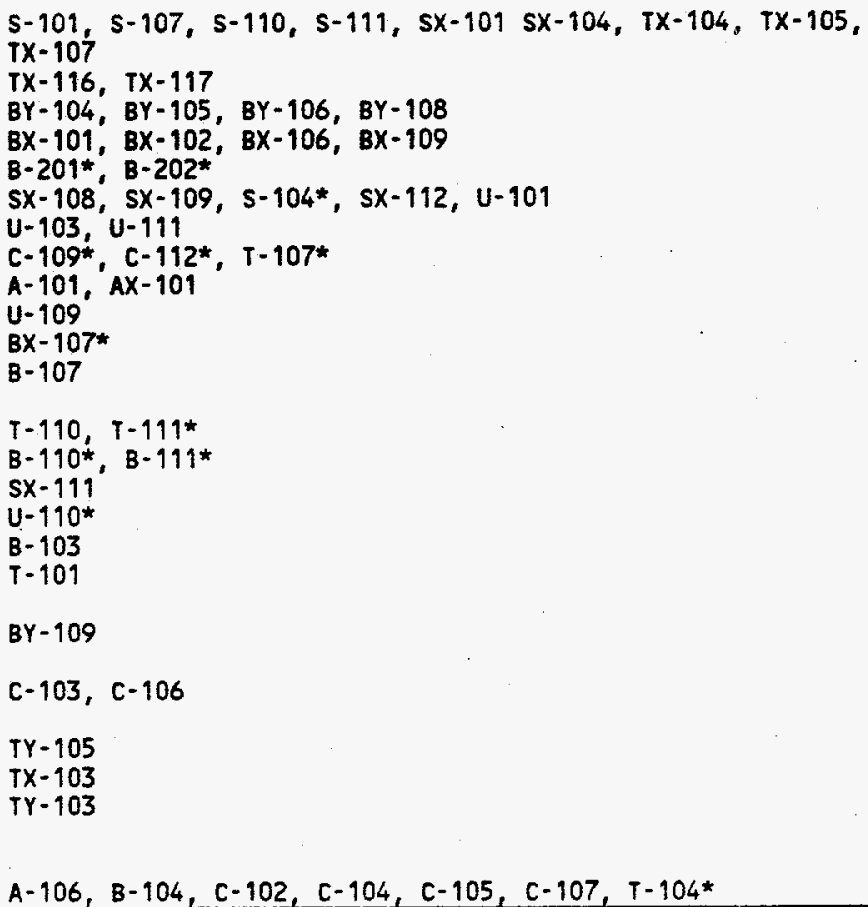 \\
\hline
\end{tabular}

DData from Hill and simpson (1994).

Number in parentheses is number of tanks in each category.

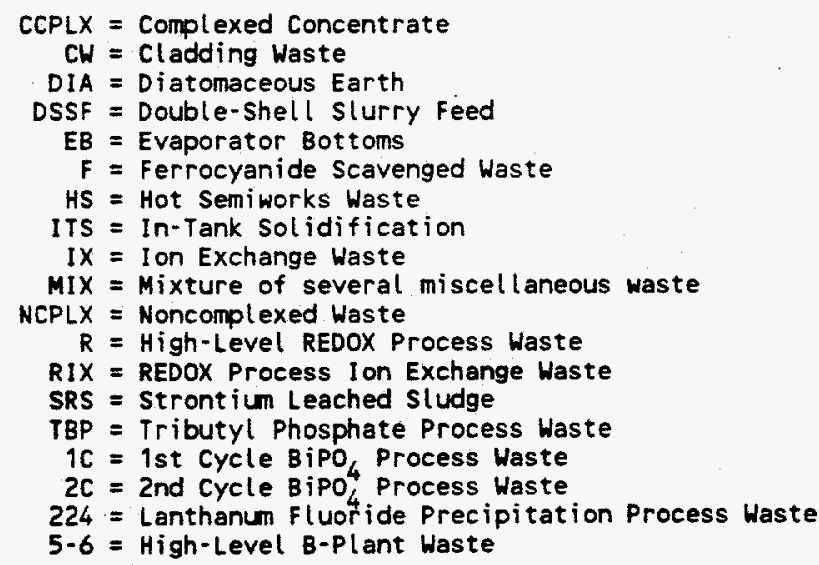

*-Waste from this SST is in archive or has been tested (Lumetta and Rapko 1994) using pretreatment process techniques. 
TRAC code data were used in conjunction with SORWT model considerations and waste inventory data to select for sampling SSTs (Table 1) which are predicted to contain significant amounts of aluminum, or chromium, or phosphate. Collectively, the 45 SSTs listed in Table 1 and 12 SSTs previously sampled contain about 46 percent, 70 percent, and 59 percent, respectively, of the total estimated SST inventory of aluminum, chromium, and phosphate. SSTs for sampling were deliberately chosen to include many of those predicted by the TRAC code to contain the highest inventories of aluminum, chromium, and phosphate. Those tanks expected to exhibit various mineral forms of aluminum that could result from aging of the waste were also considered. The ability to dissolve aluminum in sludge using enhanced sludge washing is highly dependent on the aluminum mineral form.

Even though incomplete, data contained in Brevick et al. 1994a and Brevick et a7. 1994b documentation for nine of the 12 SST Farms also were used to guide selection of SSTs for sampling. Thus, of those 17 SSTs estimated to contain the largest amount of chromium, 11 were selected for sampling. Similarly, of those 17 SSTs estimated to contain the largest amounts of aluminum, 13 were selected for sampling.

\subsubsection{Phased, Iterative Approach for Single-Shell Tank Waste Sampling.}

Current limited knowledge of tank contents prevent exact specification of bounding waste types and analyte concentrations. However, from historical data, sets of tanks were selected which likely represent bounding conditions. By using the phased, iterative sampling approach the basis for definition of additional sampling requirements can be provided. Initially a few tanks (Table 1) containing waste types with high concentrations of key analytes (or other parameters that limit processing capability) will be sampled and tests performed. Success of the process tests combined with the variability of process test results will dictate how much additional testing on other waste samples is required to provide high confidence that a robust process will result. This list represents the best estimate of the waste types needed for process testing, based on current knowledge of the waste. Waste samples from the Phase I tanks will be tested, with each set of test results used to refine the requirements for additional Phase II sampling. It is recognized that in some cases it will be difficult to obtain waste from the recommended tank. Waste from a similar tank will be acceptable for initial process testing. 


\subsubsection{Sampling Strategies for Double-She11 Tank Wastes}

Table 3 provides a preliminary list of 12 DSTs recommended for sampling and characterization for disposal purposes.

Table 3. Recommended List of Double-Shell Tanks to Sample for Disposal Purposes.

\begin{tabular}{|c|c|c|c|c|c|c|c|}
\hline \multirow{2}{*}{\multicolumn{2}{|c|}{ Selected tanks }} & \multicolumn{4}{|c|}{ Tank contents } & \multicolumn{2}{|c|}{$\begin{array}{c}\text { Previous core } \\
\text { samples }\end{array}$} \\
\hline & & \multirow{2}{*}{$\begin{array}{l}\text { Sludge } \\
\left(\mathrm{m}^{3}\right)\end{array}$} & \multirow{2}{*}{$\begin{array}{c}\text { Cumulative } \\
\text { sludge } \\
\left(\mathrm{m}^{3}\right)\end{array}$} & \multirow{2}{*}{$\begin{array}{l}\text { Supęrnate } \\
\left(m^{3}\right)^{(b)}\end{array}$} & \multirow{2}{*}{$\begin{array}{c}\text { Cumulative } \\
\text { supernate } \\
\left(\mathrm{m}^{3}\right)\end{array}$} & \multirow{2}{*}{ Date } & \multirow{2}{*}{$\begin{array}{l}\text { Number } \\
\text { of cores }\end{array}$} \\
\hline Farm & Tank & & & & & & \\
\hline$\overline{A N}$ & $\begin{array}{c}A N-104^{(c)} \\
A N-107\end{array}$ & $\begin{array}{l}999 \\
507 \\
\end{array}$ & $\begin{array}{r}999 \\
1,506 \\
\end{array}$ & $\begin{array}{l}3,028 \\
3,536 \\
\end{array}$ & $\begin{array}{l}3,028 \\
6,564 \\
\end{array}$ & & \\
\hline AW & $\begin{array}{c}A W-101^{(c)} \\
A W-106 \\
A W-103 \\
A W-105\end{array}$ & $\begin{array}{c}318 \\
800 \\
1,374 \\
1,124\end{array}$ & $\begin{array}{l}1,824 \\
2,624 \\
3,998 \\
5,122\end{array}$ & $\begin{array}{l}4,039 \\
2,850 \\
1,067 \\
2,669\end{array}$ & $\begin{array}{l}10,603 \\
13,453 \\
14,520 \\
17,189\end{array}$ & $\begin{array}{l}9-86 \\
9-86 \\
1-89 \\
6-86 \\
5-90 \\
\end{array}$ & $\begin{array}{l}1 \\
2 \\
2\end{array}$ \\
\hline$A Y$ & $\begin{array}{l}A Y-101 \\
A Y-102\end{array}$ & $\begin{array}{l}314 \\
121 \\
\end{array}$ & $\begin{array}{l}5,436 \\
5,557 \\
\end{array}$ & $\begin{array}{l}3,123 \\
3,093 \\
\end{array}$ & $\begin{array}{l}20,312 \\
23,405 \\
\end{array}$ & $7-87$ & 1 \\
\hline$A Z$ & $\begin{array}{l}A Z-101 \\
A Z-102 \\
\end{array}$ & $\begin{array}{l}132 \\
360 \\
\end{array}$ & $\begin{array}{l}5,689 \\
6,049 \\
\end{array}$ & $\begin{array}{l}3,536 \\
3,274 \\
\end{array}$ & $\begin{array}{l}26,941 \\
30,215 \\
\end{array}$ & $\begin{array}{r}3-89 \\
7-89 \\
\end{array}$ & $\begin{array}{l}2 \\
1 \\
\end{array}$ \\
\hline SY & $\begin{array}{c}S Y-102 \\
S Y-103^{(c)}\end{array}$ & $\begin{array}{c}269 \\
0\end{array}$ & $\begin{array}{l}6,318 \\
6,318 \\
\end{array}$ & $\begin{array}{l}2,491 \\
2,831 \\
\end{array}$ & $\begin{array}{l}32,706 \\
35,537 \\
\end{array}$ & $\begin{array}{c}10-88 \\
2-90 \\
8-86 \\
\end{array}$ & $\begin{array}{l}2 \\
1 \\
\end{array}$ \\
\hline
\end{tabular}

Data from Hanion (1994).

${ }^{b}$ Al so includes salt slurries.

con Current Watch List (Hanion 1994).

The 12 DSTs meet the following criteria:

- The tanks contain all the six major types of DST waste:

- Concentrated Complexed (CC) waste

- Double-Shell Slurry Feed (DSSF)

- Neutralized Current Acid Waste (NCAW)

- Neutralized Cladding Removal Waste (NCRW)

- Plutonium Finishing Plant (PFP) waste

- Dilute noncomplexed (DN) waste.

- The tanks contain about 85 vol\% of the total DST sludge inventory.

- The tanks contain about 43 vol\% of the total DST supernatant Tiquid inventory. 
- The tanks contain waste known to have high concentrations of certain components (e.g., chromium, organic carbon, sulfate, transuranic elements) that could impact selection of pretreatment processes and HLW glass volumes.

Classification on Basis of Waste Inventory. Hanlon 1994 lists current inventories of solids (sludge) and supernatant liquid in each of the 28 DSTs . Collectively, the 28 DSTs contain 7 to 8 times more supernatant 1 iquid than solids. Also, only 16 of the 28 DSTs contain significant amounts of solids; none of the AP Tank Farm tanks contain solids.

Supernatant fluids in all the DSTs are relatively we11-mixed homogeneous liquids. All of them are alkaline solutions containing large concentrations of sodium salts (e.g., $\mathrm{NaNO}_{3}, \mathrm{NaNO}_{2}, \mathrm{NaOH}, \mathrm{NaAlO}_{2}, \mathrm{Na}_{2} \mathrm{SO}_{4}, \mathrm{Na}_{2} \mathrm{CO}_{3}$, and $\mathrm{Na}_{3} \mathrm{PO}_{4}$ ). Supernatant 1 iquid in five of the DSTs also contains substantial concentrations of water-soluble organic complexants (e.g., sodium ethylenediaminetetraacetate [EDTA], sodium nitriloacetate [NTA], sodium citrate).

Sludges in the DSTs vary in chemical composition and properties depending upon the type of waste (e.g., NCAW, NCRW) from which they precipitated. Because of their different origins and compositions, DST sludges, analogous to SST sludges, are central to the development of pretreatment and vitrification technology. Unlike most SSTs the DSTs contain sludges that have generally been segregated based on process origin.

of the 13 DSTs that contain $>120 \mathrm{~m}^{3}$ of sludge, 11 are recommended (Table 3) for core sampling and characterization. These 11 DSTs contain approximately 85 percent of the total DST sludge inventory. In addition, waste from DST 241-SY-101 has been characterized and presently is being tested for development of pretreatment processes.

For DST waste, the use of grab sampling or a combination of grab sampling and core sampling, may be appropriate rather than core sampling alone. An evaluation of less expensive (than core sampling) techniques for providing representative samples from DSTs, as well as SSTs, needs to be undertaken.

Classification on Basis of Waste Type. Five waste types in DSTs (CC, DSSF, NCAW, NCRW, and PFP) are of particular importance to the development of pretreatment and vitrification technology. These five wastes contribute almost all the solids to the DSTs.

The 12 DSTs recommended for sampling include tanks containing all five major types of DST waste plus two tanks containing DN waste (Table 3). All of the tanks containing NCAW, NCRW, and PFP waste and three of the five tanks containing CC waste are recommended for core sampling. A fourth DST containing CC waste, DST 241-SY-101, has already been extensively core sampled.

Classification on Basis of Key Analytes. The DSTs selected for sampling (Table 3) contain significant concentrations of several important analytes that can directiy impact the scope of the waste pretreatment processes chosen, 
as well as the volume of glass resulting from vitrification of pretreated waste. Previous waste samples from tanks 241-AY-101 and 241-SY-102 indicate high concentrations of chromium. Achievable waste loadings in glass can be limited by the chromium content of washed waste sludges. The performance of aqueous processes (e.g., $\mathrm{NaOH}$ leaching) to remove chromium from these wastes needs to be evaluated.

Other DSTs are believed to contain waste with high concentrations of zirconium, fluoride, chloride or sulfate which can influence glass waste loadings and melter performance. Wastes in tanks 241-AW-103, 241-AW-105, 241-AY-102, 241-AZ-101, and 241-AZ-102 are representative of those with high concentrations of these analytes.

Development of technology for removal of ${ }^{137} \mathrm{Cs}$ from alkaline waste solutions will be required from NCAW, CC and DSSF waste. Wastes in tanks 241-AN-107, 241-AN-104, 241-AW-101, 241-AW-106, 241-SY-103, 241-AZ-101, and 241-AZ-102 represent these waste types.

Removal of ${ }^{90} \mathrm{Sr}$ and TRU elements from waste supernatants also may be required. Wastes in tanks 241-AN-107, 241-SY-103, and 241-AN-104 are bel ieved to contain high concentrations of these radionuclides. Tests also must be performed to evaluate methods to destroy organic complexants to precipitate ${ }^{50} \mathrm{Sr}$ and TRU. These tests will be performed on waste samples from tanks 241-AN-107 and 241-SY-103. Other DSTs containing DSSF (241-AW-101, 241-AW-06, 241-AN-104) have significant quantities of sludges that have never been adequately characterized. Analys is and testing of these samples will determine any pretreatment requirements; e.g., removal of TRU elements and/or ${ }^{90} \mathrm{Sr}$.

Existing chemical composition data from the 11 previously sampled DSTs will complement and support the data obtained in the new characterization effort recommended in Table 3. Archive samples of DST 241-SY-101 are available. Pretreatment tests with this waste will add to the information obtained from the recommended samples in Table 3.

\subsection{NUMBER OF SAMPLES REQUIRED FROM EACH TANK}

The strategy outlined in this document assumes that there is a significant degree of similarity in the behavior of wastes which fall into the same group. Analysis of the chemical properties of the waste groups show this to be true for chemical composition. However, no information is available yet regarding the variability in process test results for different samples of waste in the same group. As the strategy is applied, it will be necessary to determine the variability of wastes in a given group with respect to process testing. Although a relationship is expected between variability of chemical composition and variability of test results, the degree of correlation has not been established.

If initial test results show that great variability exists within waste type groupings or that the reaction of waste to process testing is not correlated with chemical composition in a predictable manner, the strategy for limiting the number of tanks to be sampled weakens. Additional samples will 
be required to ensure that the range of possible waste types are covered. The value of the historic data on tank composition may decrease. This result is not anticipated, but contingency plans must address it.

Because the strategy is interested in behavior of bounding types of waste, rather than behavior of waste on a tank-by tank basis, the number of samples required from a given tank is less important than the number of samples representing a waste type. For key waste types, several samples may be required; obtaining those samples from several tanks will provide the most information about the possible range of variability within a waste type. On the whole, there is not a requirement for multiple samples within a single tank. However, if more than one sample is taken for other purposes, it would prove informative to perform testing and establish in-tank variability levels. If such sampling on several tanks shows that variability of process test results within a given tank is low, further sampling should be limited to one sample per tank. Exceptions may occur when multiple samples are required to achieve the necessary volume of material.

\subsection{ADVANTAGES TO THE PROPOSED TANK SAMPLING STRATEGY}

The proposed strategy has three advantages.

1. Elimination of Redundancy. Characterization of tanks (for disposal purposes) may be done with substantially reduced numbers of samples by using historical and analytical data gathered from a limited number of tanks and process samples, defining the composition of a representative waste stream where information exists to support such an effort (such as IC waste), and applying this information to tanks that possess substantial quantities of that waste. By taking advantage of underlying patterns that exist in the distribution of wastes in the tanks, efforts and resources can be directed toward sampling and analysis of tanks which represent unknown quantities or bounding conditions.

2. Economic Optimization. Another benefit of the strategy is the potential for significant resource savings (both time and money). The phased sampling approach, coupled with the application of existing and near-term analytical information to other tanks provides an opportunity for efficient use of resources. During the sampling and analysis effort, the characterization database will be substantially increased. As more information about the composition and properties of the wastes becomes available, application of these resources can become even more selective. As noted in previous sections, sampling and analysis can be directed toward tanks representing bounding conditions, and away from tanks for which a large body of characterization knowledge already exists. 
WHC-SD-WM-TA-154

Revision 0

3. Expedite the Project. This strategy also recognizes that there are substantial technical and administrative drivers and advantages for getting sampling and analytical information as quickly as possible. The phased approach to sampling and analysis, inclusion of augers as an option for acquiring samples quickly, and the modular use of characterization data to develop inventory estimates all lead to the ability to make decisions regarding processing technology much more rapidly.

\subsection{QUALITY ASSURANCE REQUIREMENTS}

Process development tests with an appropriate selection of tank waste samples will provide information needed to support TWRS disposal decisions and to implement processes for final disposal of the waste. The strategy described in this report utilizes key selection criteria for choosing a minimum number of tank samples to adequately determine the required technical information. To assure that this strategy will achieve the TWRS goals with a low risk of failure, a quality assurance system must be in place. Quality must be assured through the following stages:

- Selected tanks must be sampled.

- Tank samples must be prepared for shipping to the performing laboratory (e.g., broken down, composited, archived).

- Controlled testing and analysis must be completed at the performing laboratory(ies).

- Testing results must be provided in a timely fashion to meet milestones necessary to support TWRS disposal plans.

The TWRS Characterization Program Quality Assurance Program Plan (Whelan et al. 1994) is the quality assurance program plan specific to the Characterization Program. This plan guides the program management activities for the Characterization Program. It establishes quality requirements for all Characterization Program work and provides a roadmap for implementing procedures.

An approved tank waste characterization plan (TCP) for implementing the sampling strategy will be issued before acquiring each tank sample. The TCP provides a description of the objectives achieved by sampling and analysis, e.g., support of relevant safety issues, and testing to support development of retrieval, pretreatment, and vitrification processes. Sample handling requirements and analytical needs are developed using the DQO process (Kupfer et al. 1994) which provides input to the TCPS. The TCP defines appropriate operating procedures for sampling the tank, and quality assurance/quality control for handling and analysis of the samples.

The Westinghouse Hanford Company (WHC) 222-S Laboratory has a quality assurance program plan (Meznarich 1994) and a quality assurance project plan (Taylor 1993) that provides the primary direction for the quality assurance/quality control for analyzing the waste tank samples at the 222-S 
Laboratory. If the Pacific Northwest Laboratory (PNL) 325 Laboratory is the performing laboratory, the analyses are guided by the 325 Laboratory quality assurance $\mathrm{plan}$ (Kuhl-Klinger 1994).

Procedures for performing process development tests with the tank samples are defined in Test Plans. Tests to be performed at the PNL 325 Laboratory are described in Rapko and Lumetta (1994). All process development work at PNL is done in accordance with requirements described in TWRS Pretreatment Technology Deve7opment Project Quality Assurance P7an (PNL 1994). Process development tests performed at laboratories other than PNL will utilize quality assurance project plans and test plans to assure that the work is done in a controlled manner.

The records associated with each test will be compiled into a data package. At a minimum, the data package will include:

- The test procedure used, including any notes taken during testing

- All analytical data reports

- A record of all calculations made in work-up and interpretation of the data

- A compilation of the test results, which will form the basis for reporting of the data in annual status reports. 


\subsection{REFERENCES}

Agnew, S. F., 1994a, Hanford Defined Wastes: Chemical and Radionuclide Compositions, LAUR-WR-94-2657, Los Alamos National Laboratory, Los Alamos, New Mexico.

Agnew, S. F., 1994b, Waste Status and Transaction Record Summary for the Northeast Quadrant, WHC-SD-WM-TI-615, Rev. 0, Westinghouse Hanford Company, Richland, Washington.

Agnew, S. F., 1994c, Waste Status and Transaction Record Summary for the Southwest Quadrant, WHC-SD-WM-TI-614, Rev. 0, Westinghouse Hanford Company, Richland, Washington.

Agnew, S. F., 1994d, Tank Layer Mode7 (TLM) Spreadsheet: NE Quadrant, A, AX, $B, B X, B Y, C$ Farms, WHC-SD-WM-TI-627, Rev. 0, Westinghouse Hanford Company, Richland, Washington.

Agnew, S. F., 1994e, Tank Layer Model (TLM) Spreadsheet: SW Quadrant, S, SX, U Farms, WHC-SD-WM-TI-630, Rev. 0, Westinghouse Hanford Company, Richland, Washington.

Anderson, J. D, 1990, A History of the 200 Area Tank Farms, WHC-MR-0132, Rockwell Hanford Operations, Richland, Washington.

Babad, H., 1994, TWRS Data Qua7ity Objectives Strategy, WHC-EP-0732, Westinghouse Hanford Company, Richland, Washington.

Be11; K. E. 1993, Tank Waste Remediation System Tank Waste Characterization Plan, WHC-SD-WM-PLN-047, Rev. 1, Westinghouse Hanford Company, Richland, Washington.

Be11, K. E. 1994, Fiscal year 1994 Tank Waste Analysis Plan, WHC-SD-WM-PLN-077, Rev. 0, Westinghouse Hanford Company, Richland, Washington

Boomer, K. D., S. K. Baker, A. L. Boldt, J. D. Galbraith, J. S. Garfield, C. E. Golberg, B. A. Higley, L. J. Johnson, M. J. Kupfer,

R. M. Marusich, R. J. Parazin, A. N. Praga, G. W. Reddick, J. A. Reddick, E. J. Slaathaug, L. M. Swanson, T. L. Waldo, and C. E. Worcester, 1993, Tank Waste Technical Options Report, WHC-EP-0616, Rev. 0, Westinghouse Hanford Company, Richland, Washington.

Brevick, C. H., L. A. Gaddis, W. W. Pickett, 1994a, Historical Tank Content Estimate for the Southwest Quadrant of the Hanford 200 West Area, WHC-SD-WM-ER-352, Rev. 0, Westinghouse Hanford Company, Richland, Washington.

Brevick, C. H., L. A. Gaddis, W. W. Pickett, 1994b, Historical Tank Content for the Northeast Quadrant of the Hanford 200 East Area, WHC-SD-WM-ER-349, Rev. O, Westinghouse Hanford Company, Richland, Washington. 
Cleveland, J. M., 1970, The Chemistry of Plutonium, Gordon and Breach Science Publishers Inc., New York, New York.

Croft, A. G., 1980, ORIGEN2-11 Revised and Updated Version of the Oak Ridge Isotope Generation and Depletion Code, ORNL-5621, Oak Ridge National Laboratory, Oak Ridge, Tennessee.

DNFSB-93-5, 1993, Recommendation 93-5 to the Secretary of Energy, Defense Nuclear Facilities Safety Board, Washington, District of Columbia.

DOE, 1987, Final Environmental Impact Statement. Disposal of Hanford Defense High-Leve7, Transuranic and Tank Wastes, DOE/EIS-0113, U.S. Department of Energy, Washington, D.C.

DOE, 1994, Recommendation 93-5 Implementation Plan, DOE/RL-94-001, U.S. Department of Energy, Richland Operations Office, Richland, Washington.

Ecology, EPA, and DOE, 1994, Hanford Federal Facility Agreement and Consent Order, as amended, Washington State Department of Ecology, U.S. Environmental Protection Agency, and U.S. Department of Energy, 01 ympia, Washington.

Grygie7, M. L. et al., 1991, Tank Waste Disposal Program Redefinition, WHC-EP-0475, Westinghouse Hanford Company, Richland, Washington.

Hanlon, B. M., 1994, Tank Farm Surveillance and Waste Status Summary Report for May, 1994, WHC-EP-0182-74, Westinghouse Hanford Company, Richland, Washington.

Hi11, J. G. and B. C. Simpson, 1994, The Sort on Radioactive Waste Type Mode 1: A Method to Sort Single-Shell Tanks Into Characteristic Groups, PNL-9814, Pacific Northwest Laboratory, Richland, Washington.

Jensen, R. D., 1994, Enhanced S7udge Washing Evaluation P7an, WHC-EP-08-05, Westinghouse Hanford Company, Richland, Washington.

Johnson, M. E., M. L. Grygiel, P. A. Baynes, J. K. Bebemeier, B. D. Zimmerman, and M. B. Triplett, 1993, Tank Waste Decision Analysis Report, WHC-EP-0617, Westinghouse Hanford Company, Richland, Washington.

Jungfleisch, F. M., 1984, Track Radioactive Components Code, Rockwell Hanford Operations, Richland, Washington.

Kuhl-Klinger, K. J., 1994, Quality Assurance Plan for Activity Conducted by the Analytical Chemistry Laboratory (ACL), MCS-033, Rev. 1, Pacific Northwest Laboratory, Richland, Washington.

Kupfer, M. J., J. M. Conner, R. A. Kirkbride, J. R. Mobley, 1994, Interim Data Quality Objectives for Waste Pretreatment and Vitrification, WHC-SD-WM-DQ0-011, Rev. 1, Westinghouse Hanford Company, Richland, Washington 
WHC-SD-WM-TA-154

Revision 0

Lawroski, S. 1955, Survey of Separations Process Other than Solvent Recovery, Chemical Engineer Prog., 51-461.

Lumetta, G. J., and B. M. Rapko, 1994, Washing and Alkaline Leaching of Hanford Tank Sludges: A Status Report, PNL-10078, Pacific Northwest Laboratories, Richland, Washington.

Meznarich, H. K., 1994, Quality Assurance Program Plan for Laboratory Analysis and Process Testing, WHC-SD-CP-QAPP-003, Rev. 1, Westinghouse Hanford Company, Richland, Washington.

Morris, K. L., 1991, In-Tank Waste Physical Property Measurement Study, WHC-SD-ER-WP-004, Westinghouse Hanford Company, Richiand, Washington.

PNL, 1994, Quality Assurance P7an for TWRS Pretreatment Technology Development Project, ETC-016, Pacific Northwest Laboratory, Richland, Washington.

Rapko, B. M., and G. J. Lumetta, 1994, Test P7an - TWRS Pretreatment Technology Development Project Sludge Washing and Caustic Leaching Screening Tests, PRT-TP-4.2, Rev. 0, Pacific Northwest Laboratory, Richland, Washington.

RHO, 1984, Track Radioactive Components Code, Rockwell Hanford Operations, Richland, Washington.

RHO, 1985, Hanford Defense Waste Disposal Alternatives: Engineering Support Data for the HDW-EIS, RHO-RE-ST-3OP, Rockwell Hanford Operations, Richland, Washington.

Schulz, W. W., and M. J. Kupfer, 1991, Candidate Reagents and Procedures for the Dissolution of Hanford Site Single-Shel7 Tank Sludges, WHC-EP-0451, Westinghouse Hanford Company, Richland, Washington.

Stevenson, R. L., P. W. Smith, 1961, "Redox Process" in Reactor Handbook, Volume 2, Fuel and Reprocessing, 2nd Edition, S. M. Stoller and R. B. Richards, E\&S, Interscience Publication Inc., New York.

Swanson, J. L. 1990, "PUREX Process Flowsheets," in Science and Technology of Tributyl Phosphate, Volume III, Applications of Tributyl Phosphate in Nuclear Fuel Reprocessing, W. W. Schulz, L. L. Burger, and J. D. Navratil Editors, CRC Press, Inc., Boca Raton, Fiorida.

Swanson, J. L., 1993, Clean Options: An A7ternative Strategy for Hanford Tank Waste Remediation, Volume 2, Detailed Description of First Example Flowsheet, PNL-8388, Volume 2, Battelle Pacific Northwest Laboratory, Richland, Washington.

Taylor, L. H., 1993, Quality Assurance Project Plan for Chemical Analysis of Highly Radioactive Mixed Waste Samples in Support of Environmental Activities on the Hanford Site, WHC-SD-CP-QAPP-002, Rev. 0 , Westinghouse Hanford Company, Richland, Washington. 
WHC-SD-WM-TA-154

Revision 0

Wagner, R. N., 1992, Hanford Waste Vitrification Plant Feed Characterization Requirements, WHC-SD-HWV-SM-001, Rev. 4, Westinghouse Hanford Company, Richland, Washington.

Whelan, T. E., et al., 1994 TWRS Characterization Program Quality Assurance Program P7an, WHC-SD-WM-QAPP-025, Rev. 0, Westinghouse Hanford Company, Richland, Washington.

Winters, W. I., L. Hansen, L. M. Sasaki, R. L. Weiss, J. F. Keller, A. C. Schmidt, and M. G. Woodruff, 1990, Waste Characterization Plan for the Hanford Site Single-Shell Tanks, WHC-EP-0210, Westinghouse Hanford Company, Richland, Washington.

Wodrich, D. D., 1994, The Hanford Site Tank Waste Remediation System Technical Strategy, WHC-SA-2335-FP, Westinghouse Hanford Company, Richland, Washington. 
WHC-SD-WM-TA-154

Revision 0

APPENDIX A

WASTE DISPOSAL TANK SAMPLING NEEDS

\section{A1.0 INTRODUCTION}

There are various end uses for chemical composition, chemical property, DQO, and physical property data obtained by analysis of the wastes in the 177 SSTS and DSTs before their retrieval for disposal. These end uses, which are defined in Wodrich 1994 and Jensen 1994, relate directly to the following TWRS functions:

1. Waste Pretreatment. Chemical and radiochemical composition data for solid and liquid phases of retrieved SST and DST wastes, both before and after water washing, are needed to devise processes for extensive and selective leaching or complete dissolution of the water-insoluble solids; to remove selected radionuclides from both acidic and alkaline waste fractions; and, if necessary, to destroy deleterious organic materials. The information will be used for development of process flowsheets and as a basis for facility design.

2. Vitrification of High-Level Waste Fraction. Chemical and radiochemical composition data for water-washed sludges; solid residues remaining after possible acid dissolution of some waterwashed sludges; and separated radionuclide fractions are needed to specify vitrification waste loadings, glass compositions, and melter operating conditions. This information is key to sizing of vitrification equipment and design of melter systems.

3. Low-Level Waste Disposal. Chemical and radionuclide composition data for as-retrieved alkaline supernatant liquids; dissolved salt cake solutions; spent sludge water wash solutions; and waste solutions generated in radionuclide removal and other pretreatment processes are needed to specify final vitrified LLW disposal forms, methodologies, and system performance.

Detailed Waste characterization data needed by each of these TWRS functions will be determined as part of the ongoing DQO process. The basis for waste characterization needs for waste pretreatment and vitrification have been defined in an interim DQO (Kupfer et a1. 1994). The information presented in Sections A2.0, A3.0, and A4.0 is consistent with these bases.

It is anticipated that the needed physical and chemical property information will be obtained from three sources, namely:

- Measurements and/or analyses performed with core segments and core composite samples and grab or auger samples from some DSTs and/or SSTS. 
- Historical bases including tank fill history to predict waste compositions

- Experiments performed with archived core composite samples to develop various waste pretreatment and vitrification technologies.

\section{A2.0 WASTE PRETREATMENT CHARACTERIZATION NEEDS}

Pretreatment of SST and DST wastes refers to application of some or all of a suite of physical and chemical processes to prepare a feed for converting the retrieved wastes into a large volume of $\mathrm{LLW}$ and a small volume of $\mathrm{HLW}$. Primary pretreatment processes currently under consideration are included in the following list. Both baseline and possible alternative processes are listed.

- Water washing of retrieved wastes

- Selective leaching of water-insoluble solids (sludges) to remove components (e.g., aluminum, phosphate, chromium) deleterious to vitrification of sludges

- Acid dissolution of water-insoluble solids (sludges)

- Removal of ${ }^{137} \mathrm{Cs}$ from alkaline waste solutions

- Removal of actinides (U, Np, Pu, and Am) from dissolved sludge solutions

- Removal of ${ }^{90} \mathrm{Sr}$ from both alkaline and acidic waste solutions

- Removal of ${ }^{99} \mathrm{Tc}$ from both alkaline and acidic waste solutions

- Destruction, as necessary, of soluble organic materials in alkaline and/or acid waste solutions.

Some extensive radionuclide separations processes, e.g., CLEAN process (Swanson 1993), also include steps for separating trivalent lanthanides and actinides and for separating ${ }^{90} \mathrm{Sr}$ from any associated nonradioactive barium.

Processes that are flexible enough to accommodate wide variations in feed composition are always a primary goal when developing radionuclide removal pretreatment technology. This goal is much easier to achieve with alkaline wastes solutions than with acidified sludge solutions. All aqueous salt cake solutions, no matter the source (i.e., which SST) of the salt cake, contain relatively large concentrations of $\mathrm{NaNO}_{3}, \mathrm{NaNO}_{2}, \mathrm{NaOH}$, and $\mathrm{Na}_{2} \mathrm{CO}_{3}$ and smaller concentrations of other sodium salts (e.g., $\mathrm{NaAlO}_{2}, \mathrm{Na}_{2} \mathrm{SO}_{4}$, and $\mathrm{Na}_{3} \mathrm{PO}_{4}$ ). Sorption processes for removal of ${ }^{137} \mathrm{Cs}$ and ${ }^{99} \mathrm{TC}$, the two principal radionuclides in salt cake solutions, are typically relatively insensitive to large changes in the concentrations of nonradioactive cations and anions in alkaline waste solutions. 
Table A-1 lists analytes, both radioactive and nonradioactive, considered to be of importance in devising pretreatment procedures for alkaline waste solutions, including SST drainable liquors, DST supernatant liquid, salt cake solutions and spent sludge wash solutions. Such pretreatment processes include both those for removal of ${ }^{137} \mathrm{Cs}$ and ${ }^{99} \mathrm{TC}$, and perhaps others (e.g., ${ }^{90} \mathrm{Sr}$ ), and those for destruction of all or part of any water-soluble organic compounds which may be present. There is a possibility that some of the nickel ferrocyanide solids originally deposited in 20 of the SSTs have undergone alkaline hydrolys is to insoluble $\mathrm{Ni}(\mathrm{OH})_{2}$ and soluble ferrocyanide species. If so, some salt cakes and alkaline supernatant liquors may contain significant amounts of soluble cyanide compounds.

Opposed to salt cakes, because of their very different origins, sludges in the SSTs are highly variable in composition from tank farm to tank farm and, in some cases, from tank to tank in the same tank farm. Acid solutions prepared from SST sludges can be expected to contain several analytes which, if present in suitably high concentrations, can seriously interfere with, or otherwise complicate performance of, pretreatment processes for removal of transuranic elements, ${ }^{90} \mathrm{Sr},{ }^{99} \mathrm{Tc},{ }^{137} \mathrm{Cs}$, and, perhaps, other radionuclides. Analytes known to be of importance in devising sludge pretreatment processes for SST sludges are enumerated in Table A-2.

Availability of sufficient amounts of actual SST wastes is essential to bench-scale development of satisfactory technology for:

- Washing of water-soluble salts from SST sludges

- Separation, e.g., gravity settling, filtration, of water-washed sludges from supernatant liquids

- Selective leaching of water-washed solids to remove constituents such as aluminum, chromium, and phosphorus

- Dissolution of water-washed sludges (Schulz and Kupfer 1991)

- Where required, destruction of organic compounds in alkaline and/or acidic waste solutions.

While, to some extent at least, other candidate chemical pretreatment processes, e.g., ion exchange removal of ${ }^{137} \mathrm{Cs}$ from alkaline solutions, can be satisfactorily developed with simulated waste solutions, water-washing, solidliquid separations, and, especially, sludge leaching and dissolution technology can only be reliably developed with actual waste solids.

Hence, a proper strategy for characterizing SST wastes must include provision for supplying experimentalists with adequate amounts, 100 to $1,000 \mathrm{~g}$ or more, of wastes from a carefully selected number of SSTs. The SSTS selected for sampling and analys is must encompass the envelope of wastes that will be encountered in plant-scale pretreatment operations. 
WHC-SD-WM-TA-154

Revision 0

Table A-1. Analytes to be Determined in Alkal ine Liquids .

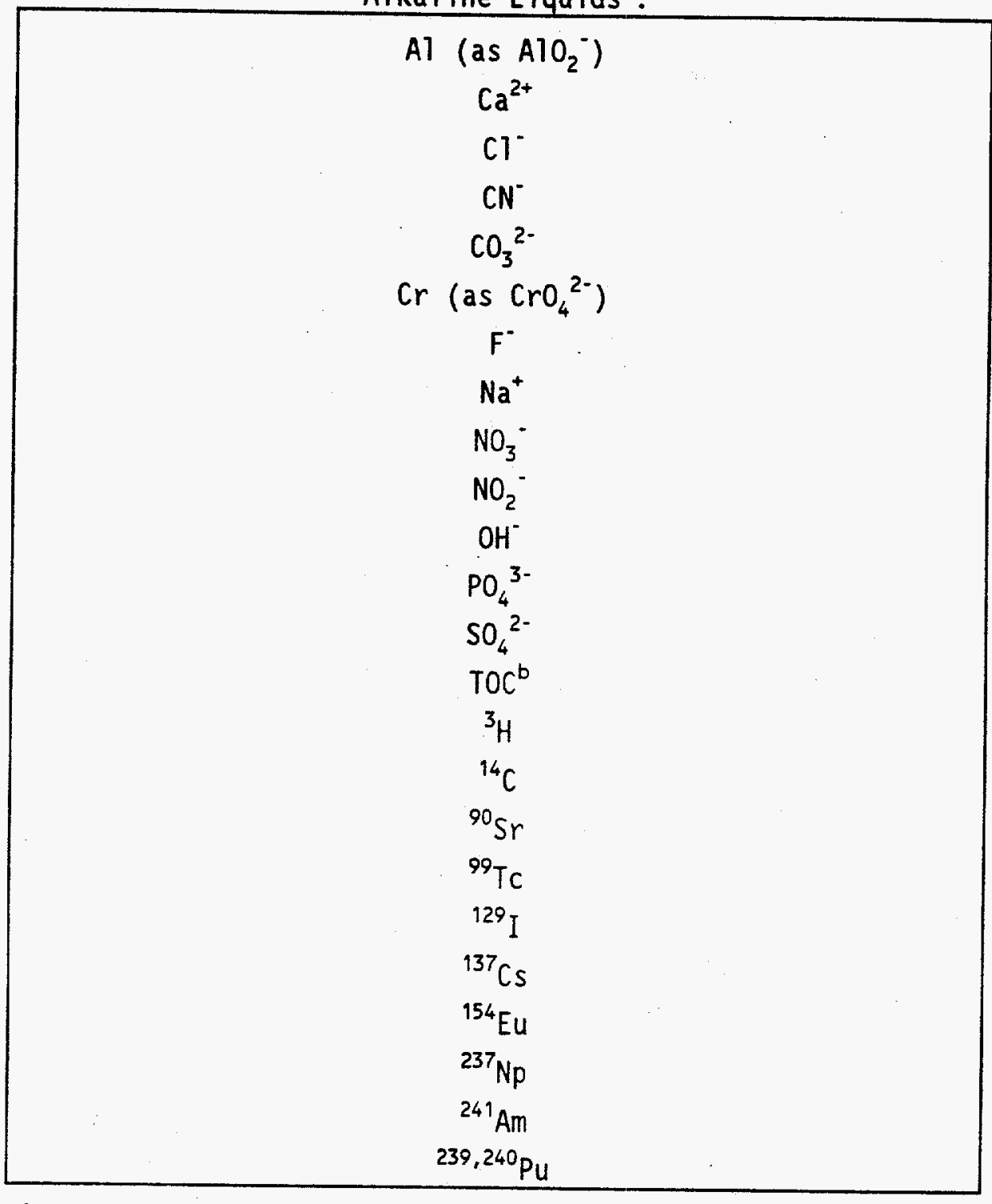

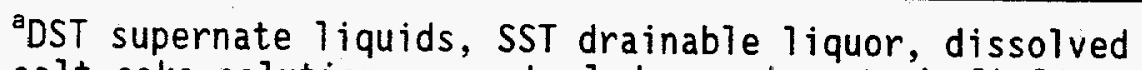
salt cake solutions, spent sludge washes, and alkaline leaches of water-washed sludge.

Total organic carbon. 
WHC-SD-WM-TA-154

Revision 0

Table A-2. Analytes of Importance to Development of Pretreatment Processes for Sludges.

\begin{tabular}{|c|c|}
\hline \multicolumn{2}{|c|}{ Analytes } \\
\hline Nonradioactive & Radioactive \\
\hline $\mathrm{Al}$ & ${ }^{90} \mathrm{Sr}$ \\
$\mathrm{Ba}$ & ${ }^{99} \mathrm{TC}$ \\
$\mathrm{Bi}$ & ${ }^{129} \mathrm{I}$ \\
$\mathrm{Ca}$ & ${ }^{337} \mathrm{Cs}$ \\
$\mathrm{Cr}$ & Total Am \\
$\mathrm{F}$ & Total Pu \\
$\mathrm{Fe}$ & Total Th \\
$\mathrm{P}$ & Total U \\
$\mathrm{Si}$ & \\
Total rare earths & \\
Total zirconium & \\
Total strontium & \\
TIC & \\
ToC & \\
\hline
\end{tabular}

Total inorganic carbon.

bTotal organic carbon. 
WHC-SD-WM-TA- 154

Revision 0

This page intentionally left blank.

$$
A-6
$$




\section{A3.0 HIGH-LEVEL WASTE FRACTION VITRIFICATION CHARACTERIZATION NEEDS}

Initial pretreatment of retrieved SST wastes will produce one or two primary types of solids as feed to a HLW vitrification facility, namely:

- Water-washed sludge

- Solid residues from leaching or solubilization of water-washed sludge.

For satisfactory vitrification of these radioactive solids, detailed information concerning their chemical and radiochemical composition is required to specify glass formulations and operating conditions for melters. Most of the required composition and inventory data will be obtained during actual pretreatment of retrieved wastes. However, before large-scale waste retrieval operations can even begin, sufficient knowledge of the composition of various types of water-washed sludge and also of residues from sludge leaching or dissolution steps must be obtained.

Tables A-3 and A-4 1 ist both radioactive and nonradioactive analytes which have previously been determined (Wagner 1992) to be important to Hanford Waste Vitrification Plant (HWVP) operation. Certain of the analytes specified in Table A-4 are known to significantly limit the mass of radioactive solid waste which can be satisfactorily vitrified in a given volume of borosilicate glass.

Table A-3. Characterization Requirements for Pretreated

Feeds to a High-Level Waste Vitrification Facility:

Radioactive Constituents ${ }^{\text {a }}$

\begin{tabular}{|c|c|}
\hline Radionuclide & Radionuclide \\
\hline${ }^{3} \mathrm{H}$ & ${ }^{154} \mathrm{Eu}$ \\
${ }^{60} \mathrm{C}$ & ${ }^{233} \mathrm{Co}$ \\
${ }^{90} \mathrm{Sr}$ & ${ }^{237} \mathrm{~Np}$ \\
${ }^{99} \mathrm{TC}$ & $239 \mathrm{Pu}$ \\
${ }^{129} \mathrm{I}$ & $240 \mathrm{Pu}$ \\
${ }^{137} \mathrm{Cs}$ & $241 \mathrm{Am}$ \\
\hline
\end{tabular}

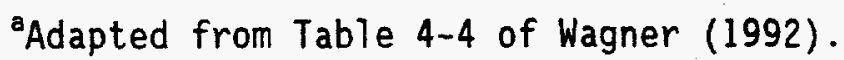




\section{WHC-SD-WM-TA-154}

Revision 0

Table A-4. Characterization Requirements for Pretreated

Feeds to a High-Level Waste Vitrification Facility: Nonradioactive Constituents. ${ }^{a}$

\begin{tabular}{|c|c|}
\hline Constituent & Constituent \\
\hline $\begin{array}{c}\mathrm{Ag} \\
\mathrm{Al}^{\mathrm{b}} \\
\mathrm{As} \\
\mathrm{B} \\
\mathrm{Ba} \\
\mathrm{Be} \\
\mathrm{Bi} \\
\mathrm{Ca} \\
\mathrm{Cd} \\
\mathrm{Ce} \\
\mathrm{Cr} \\
\mathrm{Cs} \\
\mathrm{Cl} \\
\mathrm{Cu} \\
\mathrm{Fe} \\
\mathrm{Hg} \\
\mathrm{K} \\
\mathrm{La} \\
\mathrm{Li} \\
\mathrm{Mg} \\
\mathrm{Mn} \\
\mathrm{Mo} \\
\mathrm{Na} \\
\mathrm{Nb} \\
\mathrm{Nd} \\
\mathrm{Ni} \\
\mathrm{Pb} \\
\mathrm{Pd} \\
\mathrm{Rb} \\
\mathrm{Rh} \\
\mathrm{Ru} \\
\mathrm{Sb} \\
\mathrm{Se}\end{array}$ & $\begin{array}{c}\mathrm{Si} \\
\mathrm{Sn} \\
\mathrm{Sr} \\
\mathrm{Te} \\
\mathrm{Th} \\
\mathrm{Ti} \\
\mathrm{TOC} \\
\mathrm{U} \\
\mathrm{Zn} \\
\mathrm{Zr} \\
\mathrm{F}^{\mathrm{b}}\left(\mathrm{as}^{-}\right) \\
\mathrm{Cl}\left(\mathrm{as} \mathrm{Cl}^{-}\right) \\
\mathrm{I}\left(\text { as } \mathrm{I}^{-}\right) \\
\mathrm{S}^{\mathrm{b}}\left(\text { as } \mathrm{SO}_{4}{ }^{2-}\right) \\
\mathrm{P}^{\mathrm{b}}\left(\text { as } \mathrm{PO}_{4}{ }^{3-}\right) \\
\mathrm{NO}_{2}^{-} \\
\mathrm{NO}_{3}^{-} \\
\mathrm{CO}_{3}{ }^{2-} \\
\mathrm{CN}^{-}\end{array}$ \\
\hline
\end{tabular}

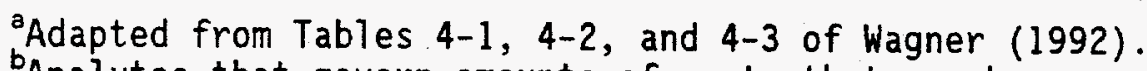

Analytes that govern amounts of waste that can be

satisfactorily vitrified into a specified volume of glass.

'Al so require $\mathrm{Cr}(\mathrm{VI}) / \mathrm{Cr}$ (III) ratio.

TOC = Total Organic Carbon 
Advanced pretreatment operations with alkaline and/or acidic aqueous solutions obtained from retrieved SST salt cake and sludge may also generate radioactive solids requiring eventual vitrification. Such solids may result, for example, from loading ${ }^{131} \mathrm{Cs}$ and/or ${ }^{90} \mathrm{Sr}$ on inorganic sorbents such as zeolites, silicotitanates, titanates, etc. It is anticipated that information and data concerning the composition and relevant properties of loaded inorganic sorbents that are potential feeds to a vitrification facility will derive from both literature sources and from bench-scale tests with actual salt cake and/or sludge solutions, cf. Section A3.0. Finally, certain advanced pretreatment processes, if applied to retrieved SST salt cake and/or sludges, will generate various concentrated and purified radionuclide fractions. Such aqueous radionuclide solutions also constitute feeds to a vitrification facility.

High-level waste solids and liquids resulting from either initial pretreatment or advanced pretreatment operations with retrieved DST wastes are identical to those produced in pretreatment of SST wastes. Hence, the analytes listed in Tables A-3 and A-4 must also be determined for DST highlevel waste fractions to develop satisfactory vitrification technology and equipment. 
WHC-SD-WM-TA-154

Revision 0

This page intentionally left blank. 


\section{A4.0 LOW-LEVEL WASTE DISPOSAL CHARACTERIZATION NEEDS}

The current TWRS strategy involves near-surface disposal of low-level wastes that meet the appropriate criteria such as U.S. Nuclear Regulatory Commission Class C-type waste. Before disposal, low-level wastes will be converted to a suitable glass disposal form.

Low-level wastes that must be solidified and disposed of may include any or all of the following aqueous solutions:

- DST supernatant liquid

- Dissolved salt cake solution

- Sludge water and/or $\mathrm{NaOH}$ washes

- Waste solutions resulting from removal of ${ }^{137} \mathrm{Cs}$ and, perhaps, other radionuclides from alkaline solutions and sludge washes

- Wastes resulting from removal of transuranic elements and other radionuclides from acidic sludge solutions.

There are several reasons to determine the chemical and radiochemical content of each of the candidate LLW solutions. Such information is essential to development of technology and equipment to produce a solid waste form suitable for final onsite, near-surface disposal. Knowledge of the chemical and radiochemical composition of the LLW fraction is also vital to assessing the performance of disposal forms and systems over time periods of interest to state and federal regulatory agencies.

Currently, the chemical and radiochemical content of liquid waste solutions that may result from waste pretreatment operations can only be estimated. Hard analytical data for these candidate low-level wastes cannot be obtained until they are generated in bench and/or pilot plant-scale tests with actual wastes. At this time, the analytes 1 isted in Table A-1 for waste pretreatment purposes are considered adequate for providing the bas is for development of a LLW vitrification process. The need for alterations to this list will be addressed in a future DQO for waste pretreatment and vitrification. 
WHC-SD-WM-TA-154

Revision 0

This page intentionally left blank.

A-12 